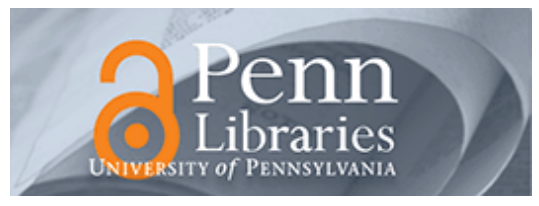

University of Pennsylvania

ScholarlyCommons

Operations, Information and Decisions Papers

Wharton Faculty Research

2006

\title{
Looking Beyond TRIA: A Clinical Examination of Potential Terrorism Loss Sharing
}

Howard Kunreuther

University of Pennsylvania

Erwann Michel-Kerjan

University of Pennsylvania

Follow this and additional works at: https://repository.upenn.edu/oid_papers

Part of the Insurance Commons

\section{Recommended Citation}

Kunreuther, H., \& Michel-Kerjan, E. (2006). Looking Beyond TRIA: A Clinical Examination of Potential Terrorism Loss Sharing. National Bureau of Economic Research, Inc., 1-39. http://dx.doi.org/10.3386/ w12069

NBER working paper 12069, accessible at http://www.nber.org/papers/w12069

This paper is posted at ScholarlyCommons. https://repository.upenn.edu/oid_papers/250

For more information, please contact repository@pobox.upenn.edu. 


\title{
Looking Beyond TRIA: A Clinical Examination of Potential Terrorism Loss Sharing
}

\begin{abstract}
The Terrorism Risk Insurance Act of 2002 (TRIA) established a public-private program to cover commercial enterprises against foreign terrorism on US soil. It was a temporary measure to increase the availability of risk coverage for terrorist acts by requiring insurers to provide coverage. Initially established to sunset on December 31, 2005, a two-year extension has been voted by Congress and signed by the President in December. This paper provides an extensive series of empirical analyses of loss sharing under this program in 2005, and a prospective analysis for 2006. Using data collected on the top 451 insurers operating in the United States, we examine the impact of TRIA on loss sharing between the key stakeholders: victims, insurers and their policyholders, and the taxpayers. By simulating the explosion of a 5 -ton truck bomb in major cities in the United States, we conclude that taxpayers are likely not to pay anything for losses below $\$ 15$ billion. For a $\$ 25$ billion loss, insurers and policyholders would handle between 80 and 100 percent of the loss depending on the property take up rate. Only for terrorist attacks where insured losses were $\$ 100$ billion would taxpayers have to pay 50 percent of the claims. Recent modifications of TRIA will transfer an even larger part of the risk to the private sector. We also show that if TRIA were made permanent in its current form some very large insurers could strategize by collecting large amount of premiums for terrorism insurance but only would be financially responsible for a small portion of the claims. Commercial policyholders from all insurers (whether or not covered against terrorism) and the federal government would absorb the residual insured losses, raising equity issues. The paper also reviews a set of possible long-term alternatives or complementary options to the current design of TRIA that could be important features of a more permanent program. We conclude that more than four years after $9 / 11$, the question as to who should pay for the economic consequences of a terrorist attack on the US has not yet received the attention it deserves. Congress or the White House should consider establishing a national commission on terrorism risk coverage before permanent legislation is enacted.
\end{abstract}

Disciplines

Insurance

Comments

NBER working paper 12069, accessible at http://www.nber.org/papers/w12069 
NBER WORKING PAPER SERIES

\title{
LOOKING BEYOND TRIA: A CLINICAL EXAMINATION OF POTENTIAL TERRORISM LOSS SHARING
}

\author{
Howard Kunreuther \\ Erwann Michel-Kerjan \\ Working Paper 12069 \\ http://www.nber.org/papers/w12069
NATIONAL BUREAU OF ECONOMIC RESEARCH
1050 Massachusetts Avenue
Cambridge, MA 02138
February 2006

This paper is partially based on a larger study TRIA and Beyond: Terrorism Risk Financing in the US, undertaken by the Wharton Risk Management and Decision Processes Center. We thank Neil Doherty, Esther Goldsmith, Scott Harrington, Paul Kleindorfer, Mark Pauly, Irv Rosenthal Peter Schmeidler and Kent Smetters for insightful comments on different aspects of the analyses provided here. The usual disclaimer applies. The views expressed herein are those of the author(s) and do not necessarily reflect the views of the National Bureau of Economic Research.

(C2006 by Howard Kunreuther and Erwann Michel-Kerjan. All rights reserved. Short sections of text, not to exceed two paragraphs, may be quoted without explicit permission provided that full credit, including $($ ) notice, is given to the source. 
Looking Beyond TRIA: A Clinical Examination of Potential Terrorism Loss Sharing Howard Kunreuther and Erwann Michel-Kerjan

NBER Working Paper No. 12069

February 2006

JEL No. H56, G22, G28

\begin{abstract}
The Terrorism Risk Insurance Act of 2002 (TRIA) established a public-private program to cover commercial enterprises against foreign terrorism on US soil. It was a temporary measure to increase the availability of risk coverage for terrorist acts by requiring insurers to provide coverage. Initially established to sunset on December 31, 2005, a two-year extension has been voted by Congress and signed by the President in December.

This paper provides an extensive series of empirical analyses of loss sharing under this program in 2005 , and a prospective analysis for 2006. Using data collected on the top 451 insurers operating in the United States, we examine the impact of TRIA on loss sharing between the key stakeholders: victims, insurers and their policyholders, and the taxpayers. By simulating the explosion of a 5-ton truck bomb in major cities in the United States, we conclude that taxpayers are likely not to pay anything for losses below $\$ 15$ billion. For a $\$ 25$ billion loss, insurers and policyholders would handle between 80 and 100 percent of the loss depending on the property take up rate. Only for terrorist attacks where insured losses were $\$ 100$ billion would taxpayers have to pay 50 percent of the claims. Recent modifications of TRIA will transfer an even larger part of the risk to the private sector.

We also show that if TRIA were made permanent in its current form some very large insurers could strategize by collecting large amount of premiums for terrorism insurance but only would be financially responsible for a small portion of the claims. Commercial policyholders from all insurers (whether or not covered against terrorism) and the federal government would absorb the residual insured losses, raising equity issues. The paper also reviews a set of possible long-term alternatives or complementary options to the current design of TRIA that could be important features of a more permanent program.

We conclude that more than four years after $9 / 11$, the question as to who should pay for the economic consequences of a terrorist attack on the US has not yet received the attention it deserves. Congress or the White House should consider establishing a national commission on terrorism risk coverage before permanent legislation is enacted.
\end{abstract}

Howard Kunreuther

The Wharton School

University of Pennsylvania

Jon M Huntsman Hall, Room 568

3730 Walnut Street

Philadelphia, PA 19104-6340

and NBER

kunreuther@wharton.upenn.edu
Erwann Michel-Kerjan

The Wharton School

University of Pennsylvania

Jon M Huntsman Hall, Room 568

3730 Walnut Street

Philadelphia, PA 19104-6340

erwannmk@wharton.upenn.edu 


\section{Introduction}

The evolution of international terrorism is now well accepted. Still mainly organized as local political actions twenty years ago, it has continuously expanded to include a large portion of extremist religious and other groups seeking to inflict fear, mass-casualties and maximum disruption to western nations' social and economic continuity and operating internationally ${ }^{2}$. Indeed, the world's 14 worst terrorist attacks (based on the number of casualties) all occurred after 1982, more than three-quarter of which took place between 1993 and 2004. A large portion of all terrorist attacks in the world during this period have been directed against U.S.-related interests and personnel. The Madrid train bombings on March 11, 2004, the coordinated London bus and underground bombings of July 7, 2005, and the bombings in Amman, Jordan in November 2005 -- attacks against three countries that were allies of the United States in the war in Iraq -- suggest that the United States remains a principal target for several international terrorist groups adhering to al-Qaeda's ideology.

Although the U.S. has been successful since 9/11 in preventing terrorist attacks on its own soil, the impact to the economy of another mega-attack or series of coordinated attacks serious concerns the government, the private sector and citizenry (Kunreuther and Michel-Kerjan, 2004 and 2005) $)^{3}$. With security reinforced around federal buildings, the commercial sector constitutes a softer target for terrorist groups to inflict mass-casualties and stress on the nation. These threats require that the country as a whole develop strategies to prepare for and recover from a (mega-)terrorist attack. Insurance is an important policy tool for consideration in this regard.

Quite surprisingly, even after the terrorist attack on the World Trade Center in 1993 and the Oklahoma City bombing in 1995, insurers in the United States did not view either international or domestic terrorism as a risk that should be explicitly considered when pricing their commercial insurance policy, principally because losses from terrorism had historically been small and, to a large degree, uncorrelated. Thus, prior to September 11, 2001, terrorism coverage in the United States was an unnamed peril included in most standard all-risk commercial and homeowners' policies covering damage to property and contents.

\footnotetext{
${ }^{2}$ Enders, W. and Sandler, T. (2006), The Political Economy of Terrorism, Cambridge University Press.

${ }^{3}$ Kunreuther, H. and Michel-Kerjan, E. (2004), "Challenges for Terrorism Risk Insurance in the United States", Journal of Economic Perspectives, Fall 2004, 18 (4), pp 201-214.

Kunreuther, H. and Michel-Kerjan, E. (2005), Insurability of (mega)-Terrorism, Report for the OECD Task Force on Terrorism Insurance, in OECD (2005), Terrorism Insurance in OECD Countries, Paris: Organization for Economic Cooperation and Development, July 5.
} 
The terrorist attacks of September 11, 2001, killed over 3,000 people from over 90 countries and inflicted insured losses currently estimated at $\$ 32.5$ billion that was shared by nearly 150 insurers and reinsurers worldwide. Reinsurers (most of them European) were financially responsible for the bulk of these losses. These reinsurance payments came in the wake of outlays triggered by a series of catastrophic natural disasters over the past decade and portfolio losses due to stock market declines. Having their capital base severely hit, most reinsurers decided to reduce their terrorism coverage drastically or even to stop covering this risk.

Hence, in the immediate aftermath of September 11, 2001, U.S. insurers found themselves with significant amounts of terrorism exposure from their existing portfolio with limited possibilities of obtaining reinsurance to reduce the losses from a future attack. The lack of availability of terrorism insurance soon after the $9 / 11$ attacks led to a call from some private sector groups for federal intervention. For example, the U.S. Government Accountability Office (GAO, formally General Accounting Office) reported in 2002 that the construction and real estate industries claimed that the lack of available terrorism coverage delayed or prevented several projects from going forward because of concerns by lenders or investors (U.S. GAO, 2002) .

In response to such concerns, the Terrorism Risk Insurance Act of 2002 (TRIA) was passed by Congress and signed into law by President Bush on November 26, $2002^{5}$. It constitutes a temporary measure to increase the availability of risk coverage for terrorist acts ${ }^{6}$. TRIA is based on risk sharing between the insurance industry and the federal government. While today it is unclear what type of long-term terrorism insurance program, if any, will emerge for dealing with the economic and social consequences of terrorist attacks ${ }^{7}$, it is of prime importance to understand how different types of attack would translate into different loss.

\footnotetext{
${ }^{4}$ U.S. General Accounting Office (GAO) (2002), "Terrorism Insurance: Rising Uninsured Exposure to Attacks Heightens Potential Economic Vulnerabilities." Testimony of Richard J. Hillman before the Subcommittee on Oversight and Investigations, Committee on Financial Services, House of Representatives, February 27.

5 The complete version of the Act can be downloaded at: http://www.treas.gov/offices/domesticfinance/financial-institution/terrorism-insurance/claims_process/program.shtml

${ }^{6}$ U.S. Congress (2002). Terrorism Risk Insurance Act of 2002. HR 3210. Washington, DC, November 26.

${ }^{7}$ Works related to terrorism insurance in the U.S that were published in the last year (other than by the authors or cited elsewhere in the text) include Cummins, D. (2005), "Should the Government Provide Insurance for Catastrophes". Paper presented at the $30^{\text {th }}$ Annual Economic Policy Conference, Federal Credit and Insurance Programs, Federal Reserve Bank of St. Louis, October 20-21; Jaffee, D. and Russell, T, (2005), "Should Governments Support the Private Terrorism Insurance Market?" WRIEC conference, Salt Lake City, August 2005; Jaffee, D. (2005), "The Role of Government in the Coverage of Terrorism Risks", Chapter 7 in OECD (2005), Terrorism Risk Insurance in OECD Countries, July 5; U.S. Department of Treasury (2005), Assessment: The Terrorism Risk Insurance Act of 2002, Washington, DC, June 30; Chalk, P. Hoffman, B., Reville, B. and Kasupski, A-B. (2005) Trends in Terrorism, Santa Monica, CA: RAND Corporation, June; U.S. Government Accountability Office (GAO) (2005), Catastrophe Risks, U.S. and European Approaches to Insure Natural Catastrophe and Terrorism Risks. GAO-05-199, Washington, D.C., February 28; CBO (2005), Federal Terrorism Reinsurance: An Update, Washington, DC, January; Brown, J., Cummins, D, Lewis, C. and R. Wei (2004), "An Empirical Analysis of the Economic Impact of Federal Terrorism Reinsurance", Journal of Monetary Economics 51, pp. 861-898; Smetters, K. (2004), "Insuring Against Terrorism: The Policy Challenge," In Litan, R. and Herring, R. (eds), BrookingsWharton Papers on Financial Services, pp. 139-182.
} 
This paper provides an extensive series of empirical analyses of loss sharing under the TRIA program for 2005 that was undertaken as part of a nine-person team research initiative we co-directed at the Wharton School last year, in collaboration with numerous firms in the insurance industry and other critical sectors, federal and international organizations that resulted in the Wharton Risk Center TRIA and Beyond report. ${ }^{8}$ President Bush signed into law a two-year extension of TRIA on December 22, 2005, the Terrorism Risk Insurance Extension Act (TRIEA) that expanded the private sector role and reduced the federal share of compensation for terrorism insured losses. We also present some analyses for the years 2006 and 2007 based on the new losssharing design (See Appendix 2 for a side by side comparison TRIA 2005 vs. TRIEA).

The paper is organized as follows. The next section focuses on the loss sharing process between insurers, policyholders and taxpayers for 2005 and 2006. Using data collected on the top 451 insurers operating in the United States, Section 3 examines the impact of the deductible on insurers' losses from terrorist attacks and provides also a simulated analysis for the 30 largest insurers (70\% of the market) for 2006 and 2007. Section 4 presents the financial impacts of terrorist attack simulations on the different stakeholders based on the explosion of a five-ton truck bomb or the crash of a commercial aircraft against one of the top 477 tallest high-rises of the country. Section 5 presents the results of a loss-share analysis for three major cities: Los Angeles (California), Houston (Texas) and New York City (New York) by combining the simulations with market share data for different line of insurance coverage in these cities. Section 6 provides a discussion as to how loss sharing between the relevant stakeholders is likely to evolve in 2006 and 2007.

In Section 7 we present a conceptual analysis as to what would happen if TRIA were made permanent. Using data on insurance markets, we show that it would be possible for some very large insurers to game the system. They would collect large amounts of premiums for terrorism insurance but only be financially responsible for a small portion of the risk. Commercial policyholders from all insurers and the federal government will absorb the residual insured losses. Such strategizing raises important equity issues as to who should pay for terrorism losses 9 . We conclude the paper by reviewing a set of possible alternatives or complementary options to the current design of TRIA that could become important features of a permanent program.

\footnotetext{
${ }^{8}$ This study undertaken in collaboration with numerous firms and federal bodies was designed to understand the importance of the insurance infrastructure in our national security agenda. For more details see the Wharton Risk Management and Decision Processes Center report TRIA and Beyond .

${ }^{9}$ Analyses in section 4, 5 and 7 focus on 2005 , which is the most recent year data are available for. It will be possible for us to undertake similar analyses for 2006 later on this year.
} 


\section{Loss-Sharing Design}

\section{Eligibility for Coverage}

Under both TRIA and TRIEA, insurers are obliged to offer terrorism coverage to all their commercially insured clients. Firms are not required to purchase this insurance unless mandated by state law, as is the case for workers' compensation lines in most states $^{10}$. The stated coverage limits and deductibles must be the same as for losses from other events covered by the firm's current policy ${ }^{11}$. This implies that if there are restrictions on a standard commercial insurance policy, then terrorism coverage will also exclude losses from these events. Thus the risks related to a terrorist attack using chemical, biological, radiological and nuclear weapons (so-called CBRN) are covered under TRIA only if the primary policy includes such coverage ${ }^{12}$.

Commercially insured losses are eligible for coverage under TRIA and TRIEA only if the event is certified by the Secretary of Treasury (in concurrence with the Attorney General and Secretary of State) as an "act of terrorism." As stated under TRIA an "act of terrorism" has to be "committed by an individual or individuals acting on behalf of any foreign person or foreign interest, as part of an effort to coerce the civilian population of the U.S. or to influence the policy or to affect the conduct of the U.S. Government by coercion" (TRIA, 2002). This distinction has been maintained under TRIEA. Therefore, an attack like the Oklahoma City bombing of 1995, which killed 168 people and had been the most damaging attack on domestic soil prior to 9/11, would not be covered under TRIA and TRIEA because it would be considered "domestic terrorism." " Under TRIA a condition for certification was that total losses from the attack must be greater than $\$ 5$ million. TRIEA establishes a "per event trigger" for federal participation: aggregate insured losses must be at least $\$ 50$ million from March 31, 2006 to January 1, 2007 and $\$ 100$ million for losses occurring in the 2007 Program Year.

\footnotetext{
${ }^{10}$ Workers' compensation coverage is mandatory for a large majority of employers in all states other than Texas where it is optional. Employers must either purchase insurance or qualify to self-insure. Workers' compensation laws do not permit employers or insurers to exclude coverage for worker injuries caused by terrorism, including those caused by acts involving nuclear, biological and chemical agents.

${ }^{11}$ In most instances, this "make available" requirement means that insurers are required to offer a policy without a terrorism exclusion or limitation. Once an insurer has satisfied this offer requirement, the insurer is permitted to offer other terrorism coverage options, such as a policy with a sub-limit.

${ }^{12}$ The extension of TRIA based on Senate bill S. 467 directs the President's Working Group on Financial Markets to study long-term availability and affordability of coverage for terrorism losses, including (1) group life and (2) nuclear, biological, chemical and radiological events. The President's Working Group has to submit a report of its findings to the House Financial Services and Senate Banking Committees by September 30, 2006.

${ }^{13}$ The distinction between what would be a "certified" event covered by TRIA and a so-called "domestic" terrorist event may difficult to establish. For example, would attacks on the U.S. soil similar to the ones perpetrated in London on July 7, 2005 be considered domestic or international? We know today that some of the terrorists where British citizens who were trained to kill in Pakistan. The frontier between domestic and international might be a grey zone in a lot of cases.
} 
While this paper focuses on commercial terrorism coverage, one should note that individuals at risk are also covered against terrorist attacks. Life insurance policies typically cover loss of life from terrorism attacks with the proceeds paid to the TRIA and TRIEA does not provide insurers with special protection against any of these individual risks (i.e., life, homeowners, automobile) ${ }^{14}$.

\section{Structure of the Partnership}

Under TRIA's three-year term that ended on December 31, 2005, there was a specific risk-sharing arrangement between the federal government and insurers for a certified event. The same logic applies under TRIEA. Figure 1 depicts the public-private loss sharing for an insurer when total insured losses are less than $\$ 100$ billion. If the loss suffered by an insurance company $i$ is less than its deductible $\left(I D_{i}\right)$, the insurer does not receive any reimbursement from the federal government. This situation is illustrated by an insured loss of $\mathrm{L}_{1}$ in Figure 1 where the insurer's payment is represented by the oblique lines. If the insured loss due to a certified terrorist attack is greater then its deductible, as depicted by $\mathrm{L}_{2}$ in Figure 1, the federal government will initially reimburse the insurer for 90 percent of the losses above its deductible, and the insurer will end up paying only 10 percent of it up front. The federal payment is represented by horizontal lines in the figure. This federal backstop provision is equivalent to free up front reinsurance above the deductible. As will be discussed later, the federal government will recoup part or all of this payment from all commercial policyholders.

The insurer's deductible is determined as a percentage of its total direct commercial property and casualty earned premiums of the preceding year for TRIA TRIEA lines (that is, lines covered by the act), and not just the premiums of clients that purchase terrorism coverage. In 2005 the premium was set at 15 percent -- if an attack had occurred in 2005, insurers would have been responsible for losses equal to 15 percent of the direct commercial property and casualty revenues that had been earned as premiums in 2004. ${ }^{15}$ If an attack occurs in 2006, insurers will be responsible for losses equal to 17.5 percent of the direct commercial property and casualty earned premiums in 2005 (20 percent in 2007). This deductible plays a very important role in determining loss sharing between insurers and the federal government and can be very large for many insurers. Using data provided by A.M. Best on their estimates of TRIA retentions for major publicly held insurance companies for 2005, we determined this deductible to be

\footnotetext{
14 After initial discussions in 2002 about the possibility of having life insurance benefit from TRIA protection, Treasury decided not to extend TRIA to group life. It concluded that since insurers had continued to provide group life coverage after $9 / 11$ even though the availability of reinsurance was reduced, there was no need to include this coverage as part of the TRIA program. Government Accountability Office (GAO) (2004), "Terrorism Insurance: Effects of the Terrorism Risk Insurance Act of 2002”, GAO-04-806T, Washington, DC, May 18. Whether group life will be included in the future will mainly depend on the conclusion of the President's Working Group to be released by the end of September 2006. It is worth noting that the extension of TRIA reduces the spectrum of coverage; for example, TRIEA excludes commercial automobile insurance, burglary and theft insurance, surety insurance, professional liability insurance; and farm owners multiple peril insurance. [D\&O insurance is still covered]

15 In 2003 the deductible under TRIA was $7 \%$ of direct commercial property and casualty earned premiums the previous year and $10 \%$ in 2004 .
} 
\$3.6 billion for American International Group (AIG) and \$2.5 billion for St. Paul Travelers. Four other companies on the list of top 10 insurers, based on TRIA-line direct earned premiums had TRIA deductibles between $\$ 800$ million and \$2.1 billion in 2005 . These are Zurich, Liberty, Chubb, and ACE. In the next section of the paper we provide an extensive analysis of this issue both for the Top 30 and Top 451 insurers in the U.S.

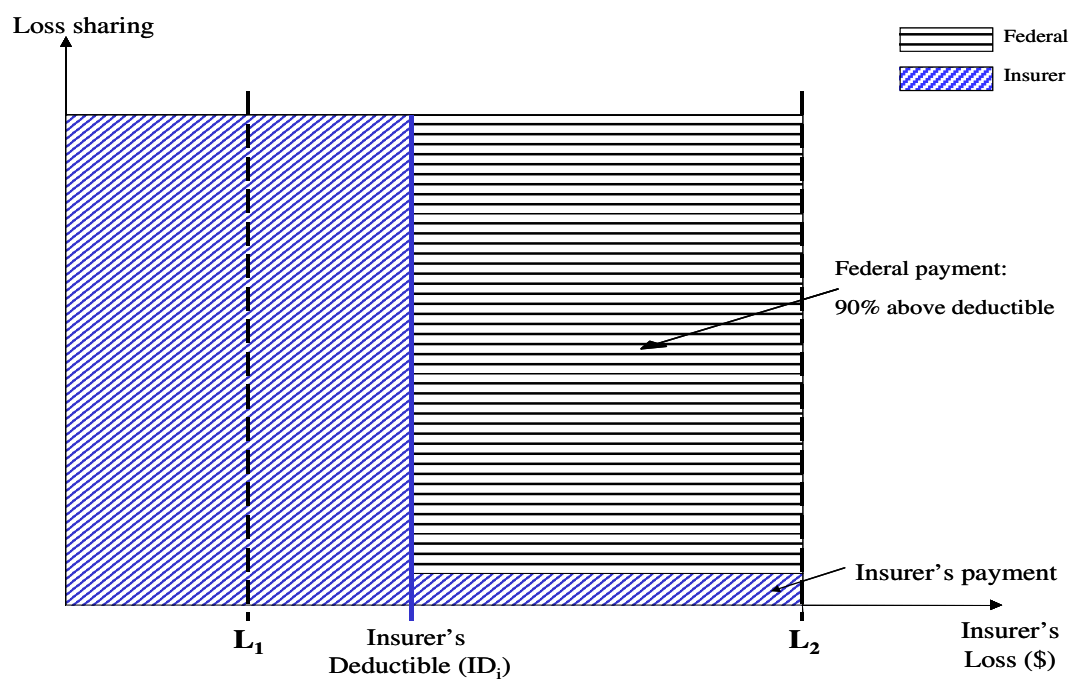

Figure 1. Loss-Sharing under TRIA and TRIEA Between an Insurer and the Federal Government [Note: If the insurance company $(i)$ loss is less than its deductible $\left(I D_{i}\right)$, the insurer is not reimbursed by the government (e.g., for an insured loss of $L_{1}$ ). If the loss is greater than the deductible $\left(L_{2}\right)$, the government reimburses the insurer for 90 percent of the losses above its deductible, and the insurer pays 10 percent.]

If the insurance industry suffers terrorism losses that require the government to cover a portion of companies' claims, then these outlays will be fully or partially recouped ex post. More specifically, the federal government will recoup the portion of its payment between the total insurers' outlays and a market aggregate retention amount, which is defined by the law ( $\$ 15$ billion in 2005; $\$ 25$ billion in 2006; $\$ 27.5$ billion in 2007); that is called the "mandatory recoupment". This mandatory recoupment ${ }^{16}$ is obtained by levying a surcharge on all commercially insured policyholders, whether they had purchased terrorism insurance or not. If the insured losses exceed $\$ 100$ billion during the year, then the U.S. Treasury will determine how the losses above this amount will be covered ${ }^{17}$.

This federal recoupment surcharge "may not exceed, on an annual basis, the amount equal to 3 percent of the premium charged for property and casualty insurance

\footnotetext{
${ }^{16}$ The law is ambiguous as to what will happen if the total insurers' outlays are above this market aggregate retention.

${ }^{17}$ The TRIA legislation states that "If the aggregate insured losses exceed $\$ 100,000,000,000$, (i) the Secretary shall not make any payment under this title for any portion of the amount of such losses that exceeds $\$ 100,000,000,000$; and (ii) no insurer that has met its insurer deductible shall be liable for the payment of any portion of that amount that exceeds $\$ 100,000,000,000$. Congress shall determine the procedures for and the source of any payments for such excess insured losses." $§ 103(\mathrm{e})(2)(\mathrm{A})$. TRIEA does not modify this.
} 
coverage under the policy."18 Insurers play the role of intermediaries by levying this surcharge against all their property and casualty policyholders ${ }^{19}$, whether or not they had purchased terrorism insurance, and transfer the collected funds to the Department of Treasury. In other words, taxpayers would have paid insured losses between $\$ 15$ billion and $\$ 100$ billion in 2005. In 2006, they will pay insured losses between 25 and 100 billion of dollars. The law indicates that the federal government could also recoup part of that payment (so-called "discretionary recoupment") but is not clear on that process; in this paper we assume that this is not the case.

Figure 2 depicts the repayment schedule in 2006 between the insurers (the area comprising blue oblique lines), all commercial policyholders (solid gray area) and the taxpayers (area comprising of horizontal lines) after the federal government has reimbursed all insurers for 90 percent of their claims payments above their deductible level (for those suffering loss above their TRIEA deductible). In the example we consider here, since the total insured losses $L$ are greater than $\$ 25$ billion but total payments by insurers are below the market aggregate retention of $\$ 25$ billion, we assume the government recoups a portion of its payments from commercial policyholders with the remaining amount paid by U.S. taxpayers.

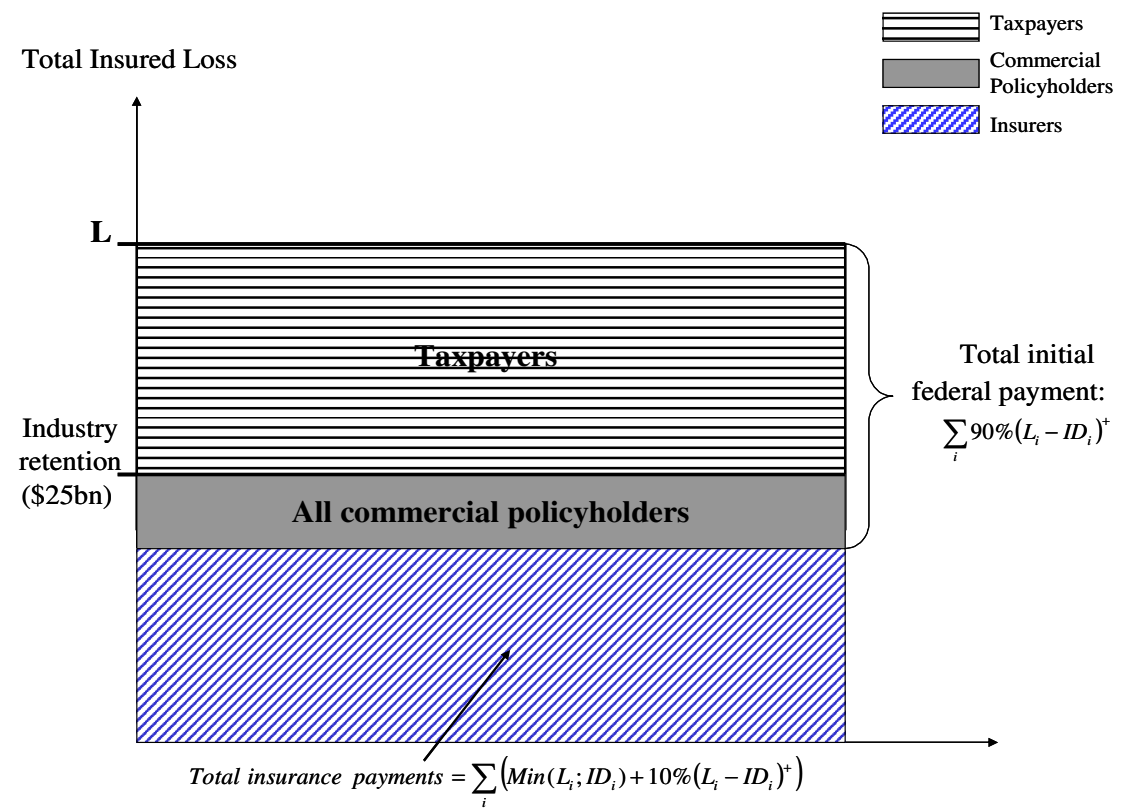

Figure 2. Loss Sharing under TRIEA between Insurance Industry, All Policyholders and Taxpayers in 2006

[Note: In this example, because the total insured loss $L$ exceeds $\$ 25$ billion, but total payments by insurers are below the market aggregate retention of $\$ 25$ billion, we assume the government recoups a portion of its payments from commercial policyholders with the remaining amount paid by U.S. taxpayers.]

\footnotetext{
${ }^{18}$ TRIA, Section $103(\mathrm{e})(8)(\mathrm{C})$.

${ }^{19}$ There is no statement in the legislation or its interpretation that specifically indicates that only the commercial policyholders are taxed. We have discussed this point with insurers and reinsurers. They have assumed that because TRIA applies only to commercial enterprises, the Department of Treasury will tax only commercial entities after a terrorist attack.
} 


\section{Empirical Analysis of Insurer Deductible/Surplus Ratios}

We conducted a series of empirical analyses on the impact of TRIA and TRIEA on loss sharing between those directly targeted by a terrorist attack, their insurers and other interested parties such as commercial policyholders and U.S. taxpayers ${ }^{20}$. In this section and the next two others, we concentrate our analyses on the following two aspects: the effect of the program's deductible feature, and the effect of different terrorist attacks on losses and loss-sharing.

We first examined TRIA and TRIEA's deductible feature and its effect on the level of exposure to a terrorist attack insurers might have. We found that the larger an insurer's Deductible/Surplus $(D / S)$ ratio, the more exposed the insurer is to losses from any given terrorist attack. We determined how the $D / S$ ratio for the top 451 insurers operating in the country $^{21}$ has changed over the three years of TRIA's operation (2003-2005). Data necessary to do a similar analysis for 2006 (TRIEA line insurers' direct earned premiums) are not available yet. For that reason, we also computed the $D / S$ ratios for 2006 and 2007 for the top 30 insurers under the deductible increases to 17.5 percent in 2006 and to 20 percent in 2007 but using extrapolated figures from the last three years. We then compared $D / S$ over the five-year period 2003-2007 for each insurer (see Appendix 1).

We then analyzed in the next sections the impact of different simulated terrorist attacks on the losses experienced by the victims, insurers, policyholders, and taxpayers, and the likely differences in large urban areas. We differentiated workers' compensation from other TRIEA-covered lines. While we have the data to undertake such analyses for large cities throughout the country, in this paper we provide the results only for one or two cities in three states: Texas (Houston and Dallas), California (Los Angeles and San Francisco) and New York (New York City).

\section{The notion of policyholders' surplus}

We start with our analysis of the impact of the deductible feature of TRIEA. Insurer capital represents the net worth of the company (assets minus liabilities). Capital enables the insurer to pay any losses above those that were expected. It serves as a safety net to support the risk an insurer takes on by writing insurance, and it helps ensure that the insurer will be able to honor its contracts. As such, insurers' capital supports the personal safety nets of homeowners, business owners, workers, dependents of heads of households and others who rely on insurance to provide financial compensation to rebuild their lives and businesses after covered losses occur.

\footnotetext{
${ }^{20}$ The analyses undertaken in this paper are based on data provided by A.M. Best and Risk Management Solutions, discussions with key stakeholders concerned with terrorism insurance, and by responses to a questionnaire designed by the Wharton Risk Center and distributed to insurers by the American Insurance Association and the Property Casualty Insurers Association of America in 2005.

${ }^{21}$ The top insurers were those ranked by 2004 TRIA-line direct earned premium (DEP); that is the measure used to calculate insurers' 2005 deductible under TRIA. These insurers all had a total TRIA-line DEP equal to or above $\$ 10$ million in 2004.
} 
Insurer capital is traditionally referred to as "policyholders' surplus" (also called "surplus" for short). Despite the connotation of the term "surplus," there is nothing superfluous about it -- it is, in fact, an essential component supporting the insurance promise. The cost of that capital is an insurer expense that must be considered in pricing insurance, along with expected losses, sales and administrative expenses for policies written. Consider, for example, insurance for property damage caused by hurricanes. An insurer's expected losses are relatively low, because in a typical year the policyholder will not suffer a hurricane loss. However, losses could also be quite high -- far in excess of those expected at the time policies are priced -- as illustrated by the 2005 hurricane season. In the event of a serious hurricane, a substantial portion of the loss must be paid from insurer capital. For terrorism coverage, maximum losses are extremely high relative to expected losses, which makes the capital issue critical.

\section{The evolution of the D/S ratio under the three-year TRIA terms: 2003-2005}

Given the obligation of insurers to offer terrorism insurance to all their commercial policyholders under TRIA, the amount of loss that an insurer will eventually bear is based on its deductible. As described in the previous section of this paper, the insurer's deductible under TRIA (and TRIEA) is determined as a percentage of its total direct earned premiums (DEP) during the preceding year for TRIA lines. For each of the top 451 insurers A.M. Best provided us with the premiums written in TRIA commercial lines ${ }^{22}$, to allow us to determine what the deductible $(D)$ of each of these insurers had been under TRIA. Although we do not know the insurers' exact terrorism exposure ${ }^{23}$, we will assume that they are providing this TRIA-based coverage to a large proportion of their policyholders in the urban areas we consider here. We can also distinguish P\&C from workers' compensation market shares. Our interest is in determining how vulnerable insurers are to the possibility of suffering a large loss relative to their surplus. Those insurers with large deductibles $(D)$ relative to their surplus $(S)$ are the ones most at risk if they are providing terrorism coverage to most of their policyholders.

Figure 3 depicts the evolution of the $D / S$ graphically for our sample of 451 insurers for these same three years $(2003,2004$ and 2005). For each year, we plot the number of insurers whose $D / S$ ratio lies between different percentage ranges in increments of 5 percent (e.g., [0\% and 4.99\%]; [5\% and 9.99\%], etc).

Of the total, 294 insurance companies providing terrorism insurance in the U.S. had a $D / S$ ratio lower than 10 percent in 2003, compared with 139 insurers in 2005 . If we consider higher $D / S$ ratios, more than half of the firms had a $D / S$ ratio greater than 15 percent in 2005 compared with less than one-sixth of the insurers in 2003. In 2003, only 36 insurers had a $D / S$ ratio above 20 percent. There were 80 such insurers in 2004 . In

\footnotetext{
22 The original sample was made of all insurers with a TRIA-line total earned premium higher than $\$ 10$ million in 2002, 2003 and 2004. Because the number of these insurers varied from one year to the next (establishment of new companies, mergers, bankruptcies, etc.), we selected a consistent sample of 451 insurers over the three years 2002-2004 that we used to determine the evolution of the $D / S$ ratio under TRIA 2003-2005.

${ }^{23}$ This information would obviously be highly valuable but is not yet publicly available.
} 
2005, 162 insurers (more than 35 percent of the sample) had a $D / S$ ratio greater than 20 percent.

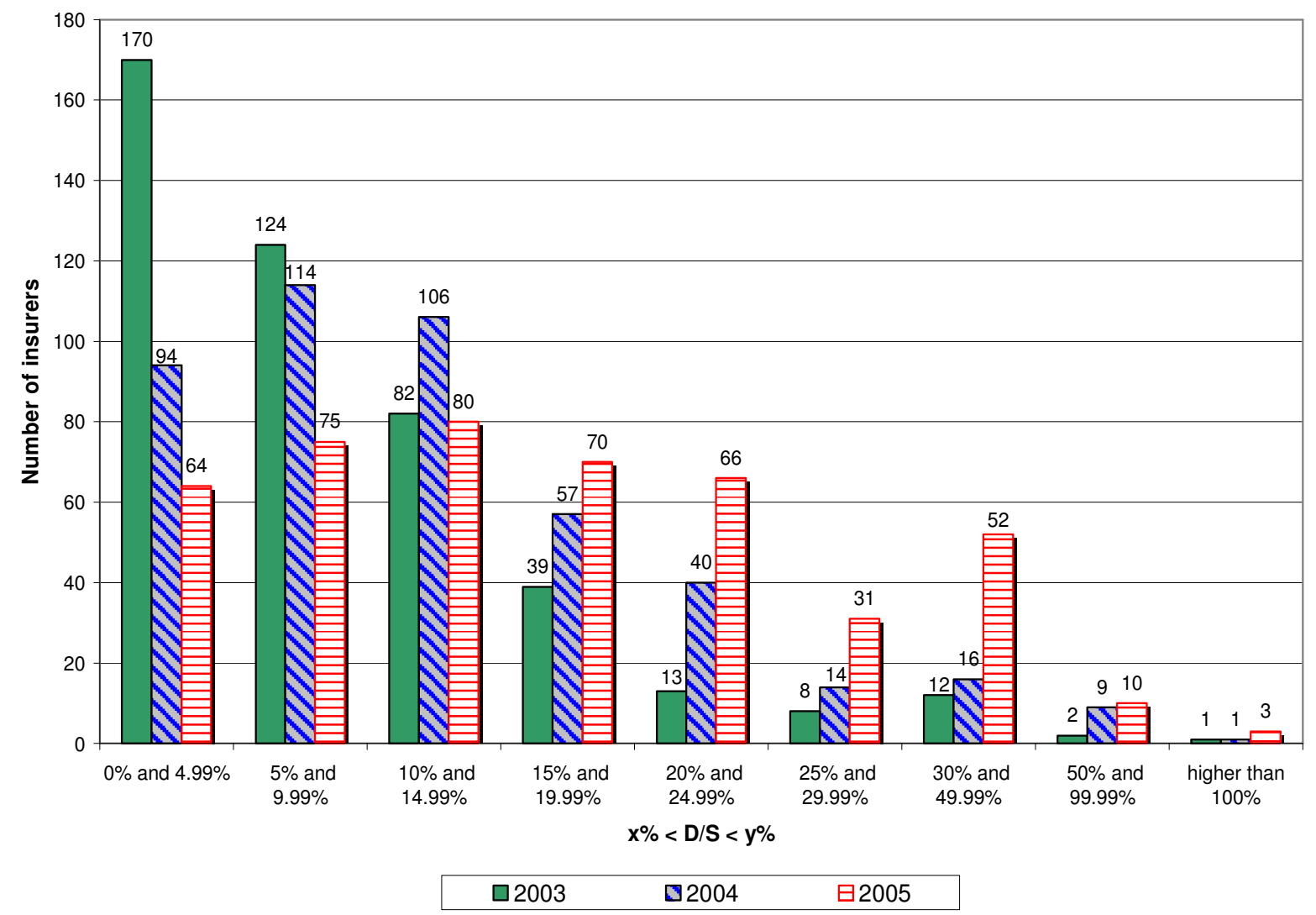

Figure.3. Change in $D / S$ Ratio for the Top 451 Insurers under TRIA (2003-2005)

\section{Focus on the Top 30 insurers - TRIA \& TRIEA, 2003-2007}

Insurers writing policies in an urban area know that there is some chance that the loss from a terrorist attack could reach or exceed their deductible $(D)$. We focus our second series of analyses of the impact of TRIA on insurers for the 30 largest companies based on direct earned premiums in TRIA lines the preceding year. These companies wrote premiums that comprised 70 percent of the total insurance market ${ }^{24}$.

This analysis is based on the TRIA deductibles of 7 percent (2003), 10 percent (2004) and 15 percent (2005) of the direct earned premiums (DEP) for TRIA line policies during the previous year. The data show clearly that there has been a major shift over the past 3 years as the TRIA deductible percentage has increased. For example, as shown in Figure 4, only 5 insurers had a $D / S$ ratio exceeding 10 percent in 2003 while more than half were in this category in 2005 . Of the top 30 insurers, 8 of them have a $D / S$ ratio exceeding 20 percent in 2005, while only 1 was in this range in 2003.

It is interesting to see how the extension of TRIA affects the $D / S$ ratio of these 30 insurers for 2006 and 2007. We thus also analyze an increased deductible up to $17.5 \%$ of

\footnotetext{
${ }^{24}$ The top 30 insurers' TRIA line direct earned premiums in 2004 were about $\$ 147$ billion of dollars out of the $\$ 210$ billion provided by the top 451 insurers of our sample in that same year.
} 
TRIA-line direct earned premiums (DEP) in 2006, and to 20 percent in 2007. However, in order to determine " $D / S$ (2006)" and " $D / S$ (2007)" for each of the 30 companies under this scenario, we need to know what would be their TRIA-line DEP and their surplus in 2005 and 2006, respectively. As these data are not available yet we do extrapolate from the past. We base our analysis on the annual percentage change in these two numbers over the three-year period (2002-2004) for each of the thirty companies ${ }^{25}$. We then extrapolate these figures for the next two years to estimate direct earned premiums (DEP) for TRIA lines and surplus $(S)$ for 2005 and 2006.

Figure 4 depicts the number of insurers (y-axis) whose $D / S$ exceeds pre-specified values of $x$ percent (x-axis); years 2003, 2004 and 2005 are exact figures, 2006 and 2007 result from our prospective analysis. Should this estimation be right, 18 of the top 30 insurers would have a TRIEA deductible higher than 10 percent of their surplus in 2007; for 13 of them that would be higher than 20 percent (vs. 8 in 2005 and 1 in 2003), including for 6 of the 10 largest insurers (Appendix provides the complete set of results). Moreover, none of theses 30 insurers had a D/S ratio higher than 50\% in 2005. there will be 3 such insurers in 2006 (50\%, 56\% and 66\%, respectively) and 2007 (the D/S ration increased dramatically up to $57 \%, 70 \%$ and $100 \%$ ).

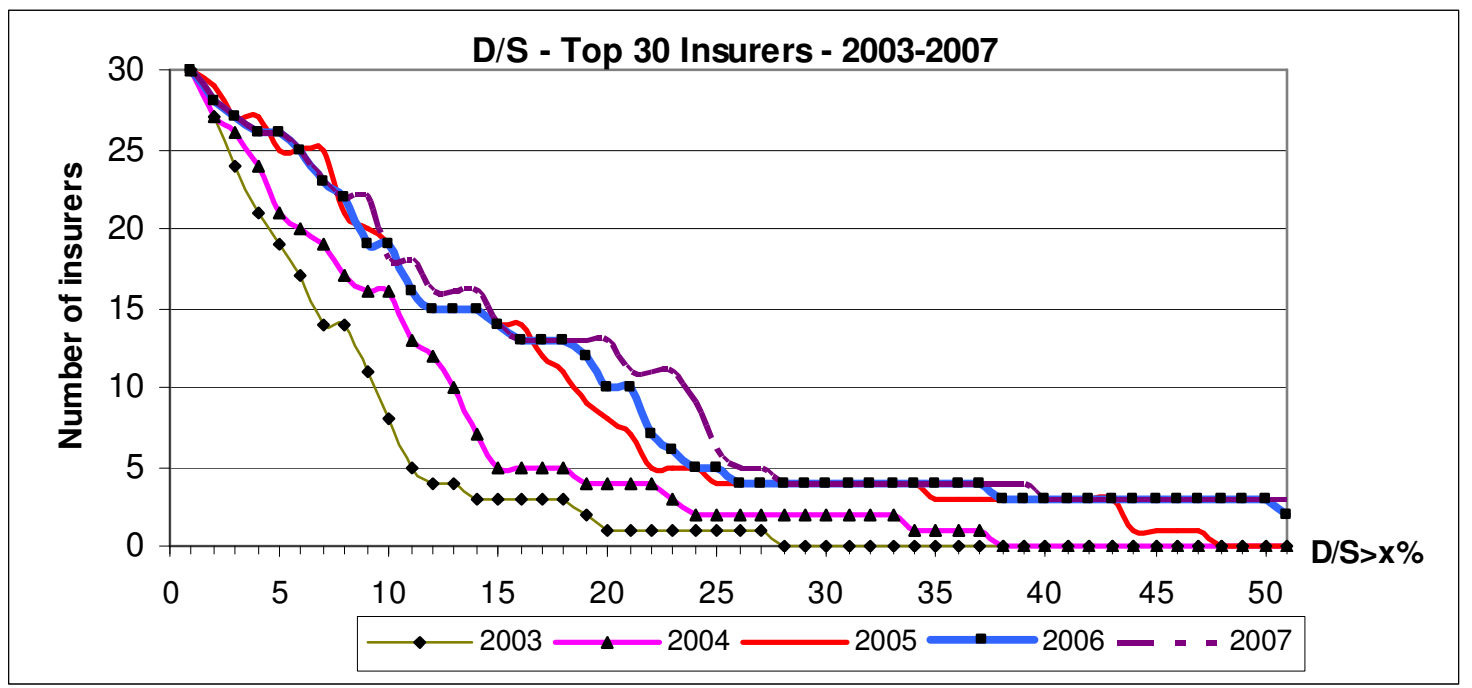

Figure 4. Number of the Top 30 Insurers whose $D / S$ Exceeds Pre-specified Values of $x$ Percent

\section{Constructing Terrorist Attack and Loss-Sharing Scenarios}

Due to the difficulty in estimating the likelihood of a terrorist attack, insurers utilize scenarios to determine their maximum exposure to a range of possible attacks that

\footnotetext{
${ }^{25}$ This can be done for the largest companies as changes are "relatively" stable over these three years and consistent with the market. However, extrapolating that for the other 431 smaller insurers does not work well because for most of them there is a huge difference between (2004/2003) and (2003/2002): taking the mean of it is not likely to reflect what the evolution has really been from 2004 to 2005 .
} 
vary by location and mode of attack ${ }^{26}$. However, few insurers consider the likelihood of these scenarios occurring in determining their exposure ${ }^{27}$.

Given insurers' interest in determining their exposure using deterministic scenarios, and to more fully understand the nature of the economic and human losses from a terrorist attack on business property, we constructed a set of scenarios to analyze the impact of financial losses between the non-insured victims, the insurers and the taxpayers under TRIA and TRIEA. We also utilized these scenarios to analyze the effect on the distribution of losses should TRIA have not been renewed so that the private market (e.g., insurers, property owners and/or employers) would be responsible for all the losses.

As discussed earlier, there are no easy answers to these loss allocation questions -they will be determined by the nature and location of the terrorist attacks and the number of insurers providing coverage. For example, if the attack is a relatively small one on a single building, and if large insurers with high deductibles cover the target building, then there will be little, if any, federal government involvement in loss payments. However, if a few smaller companies with low TRIA deductibles cover the target building, then the federal government will pay a significant portion of their losses, and then will partially or fully recoup these payments later from all policyholders purchasing commercial insurance.

Evidence indicates that most insurers focus on damage from two-to-ten-ton truck bombs in determining the losses they could suffer from a terrorist attack ${ }^{28}$. As an element of comparison, the attack in the front of the Alfred P. Murrah Federal Building in Oklahoma City in 1995 was perpetrated with a two-and-a-half-ton truck bomb. One reason for this focus is that A.M. Best uses this type of scenario in analyzing the impact of a terrorist attack on insurers' balance sheets. Although other scenarios could be used to evaluate losses from a terrorist attack ${ }^{29}$, we analyze the effect on property damage and workers' compensation losses of a five-ton truck bomb exploding in each of the United States' 447 largest commercial high-rise buildings. ${ }^{30}$.

\footnotetext{
26 When asked the question "Does your company consider scenarios in its catastrophe/exposure management process?" 92 percent of the insurers who responded to the Wharton questionnaire answered "Yes". One company responded to the above question by noting: "Our company uses deterministic terrorist attack scenarios, and the associated Probable Maximum Loss (PML) estimates of these scenarios, to establish and manage exposure concentrations within major metropolitan areas and/or surrounding landmark properties.”; see Wharton Risk Center (2005).

${ }^{27}$ As illustrated by the following responses to the question: "Do you take estimates of the likelihood of the various known scenarios into account when making underwriting decisions?":

"Not really. There is little historical data to predict future events."

"Likelihood is very unpredictable for terrorist acts."

"Our company does not believe that estimates of the frequency of terrorist attacks are credible at a country, regional or specific property level.”; see Wharton Risk Center (2005).

${ }^{28}$ For example, $90 \%$ of the Wharton questionnaire discussed above indicated that they were using that type of scenario in evaluating their exposure: 7 of the 10 insurers responding to the questionnaire indicated that they used 5-ton bomb scenario and 2 insurers indicated they used a two-ton truck bomb scenario. See Wharton Risk Center (2005). Ibib.

${ }^{29}$ For example, the RAND Corporation has undertaken a detailed study on the impact of aircraft attacks on high rises in the United States.

${ }^{30} \mathrm{We}$ are grateful to Andrew Coburn from Risk Management Solutions who provided us with these data.
} 


\section{Scenario Methodology}

Figure 5 describes the methodology for allocating losses from a specific scenario to the potential victims as well as to the insurers and the federal government immediately after a terrorist attack.

The loss allocation process can be divided into several steps:

- Step 1: Identify the nature of the terrorist attack: What's the target (represented by the target picture in figure below)? What mode of attack? Is the attack considered a "certified" or "non-certified" event? What are the direct losses potentially by insurance?

- Step 2: Determine losses covered by insurance. What was the insurance take-up rate at the target location? What portion of the losses is actually covered by insurance (by line)?

- Step 3: Determine what proportion of losses is assumed by each of the affected parties. Who's paying what? What insurers are responsible for what part of the insured losses? How the loss-sharing process under TRIA and TRIEA does operate? (the table at the top of the figure below)

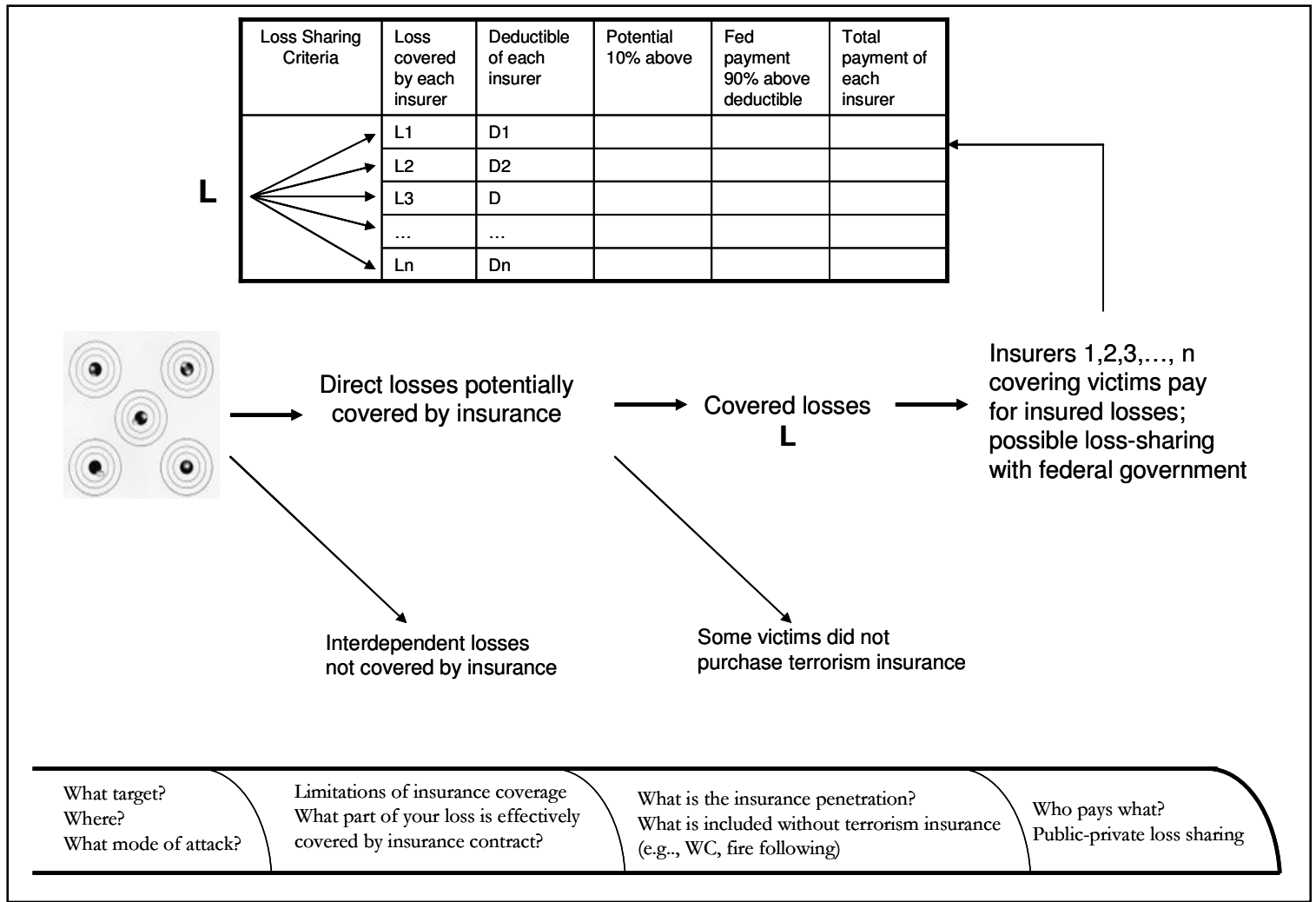

Figure 5. Methodology for Loss-Allocation Process

Figure 6 provides the distribution of loss for each of 447 commercial high-rise buildings on two major insurance lines covered by TRIA (and TRIEA): property (including business interruption) and workers' compensation. The explosion of a five-ton truck bomb would inflict not only disastrous damage to the specific building that terrorists want to target, but also to other adjacent structures. The impact would mainly 
depend on the type of building and the number of employees who work there ${ }^{31}$. For example, the distribution of losses described in Figure 6 indicates that a five-ton truck bomb on Building A would inflict $\$ 4.7$ billion in workers' compensation losses and $\$ 3.9$ billion in property losses ${ }^{32}$. An attack on Building B, in a different city, would inflict $\$ 6.8$ billion in workers' compensation losses and $\$ 8.7$ billion in property losses. The maximum combination of property and workers' compensation losses is estimated to be between $\$ 15$ and 16 billion for a single event (Buildings B and C).

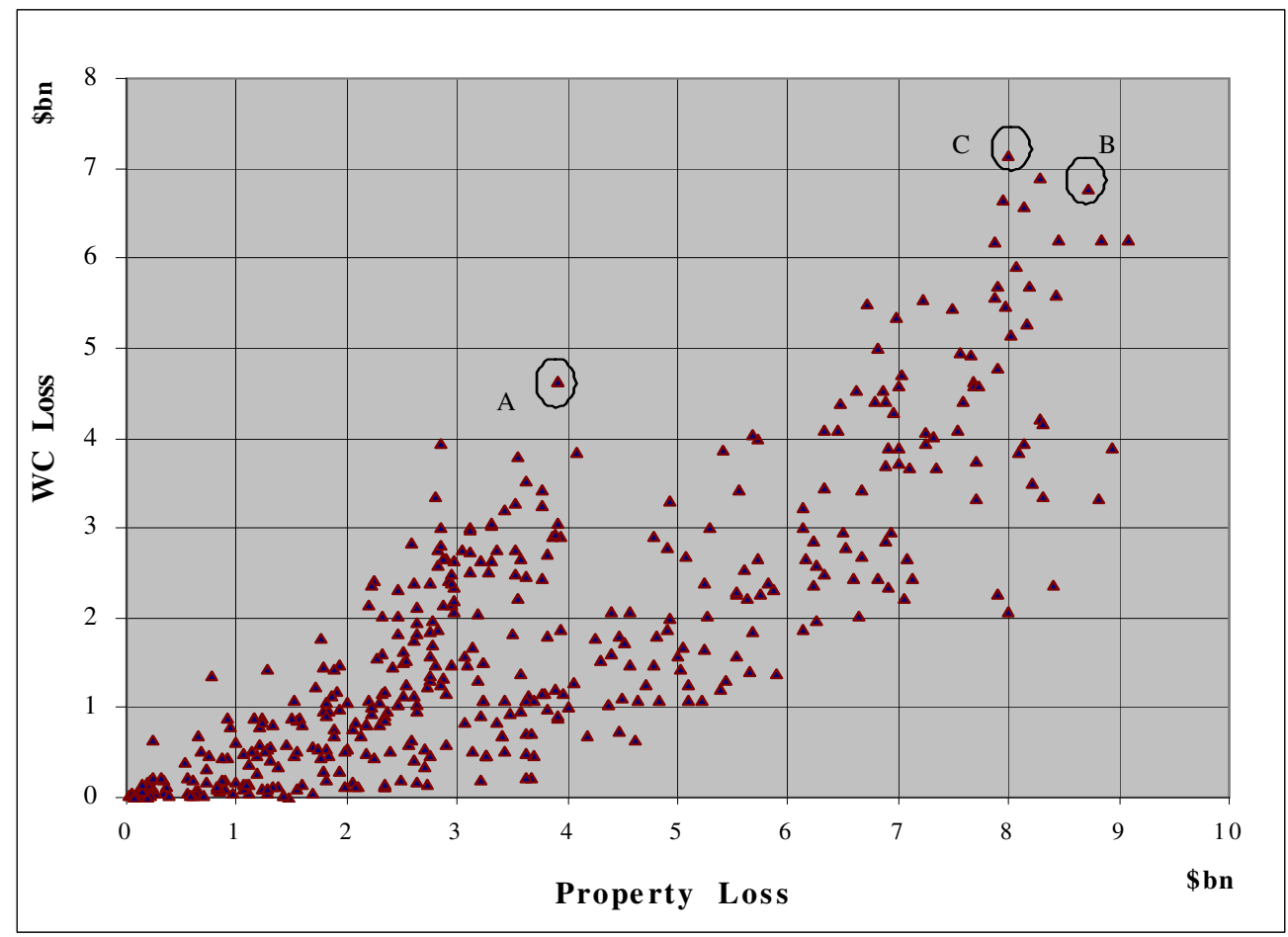

Figure 6. Projected Property Losses and Workers' Compensation Losses from Five-Ton Bomb Attacks to 447 High-Rise Buildings in the United States (in \$ billion)

[Each triangle represents one specific high-rise building used in the simulation;

Triangles A, B, and $\mathrm{C}$ are three specific buildings we discussed in the core of the text]

Similar simulations can be run using a scenario of an aircraft crashing against each of the 447 high-rise buildings (Figure 7). Such a simulation reveals that the magnitude of loss for property and workers' compensation for each of the 447 simulations would be lower. Workers' compensation maximum losses are likely to be capped at $\$ 3$ billion $^{33}$ and property at $\$ 8$ billion for different buildings. As with the truck bomb scenario, if simultaneous attacks were to occur in different locations, the losses would be additive.

\footnotetext{
${ }^{31}$ For the simulation, we assume that the attack would occur at 10 a.m. on a Wednesday -- a time when most employees would be in the building.

${ }^{32}$ For obvious reasons we do not reveal here the nature of any of these targets.

${ }^{33}$ The insured WC losses due to the $9 / 11$ attacks were $\$ 1.3$ billion.
} 


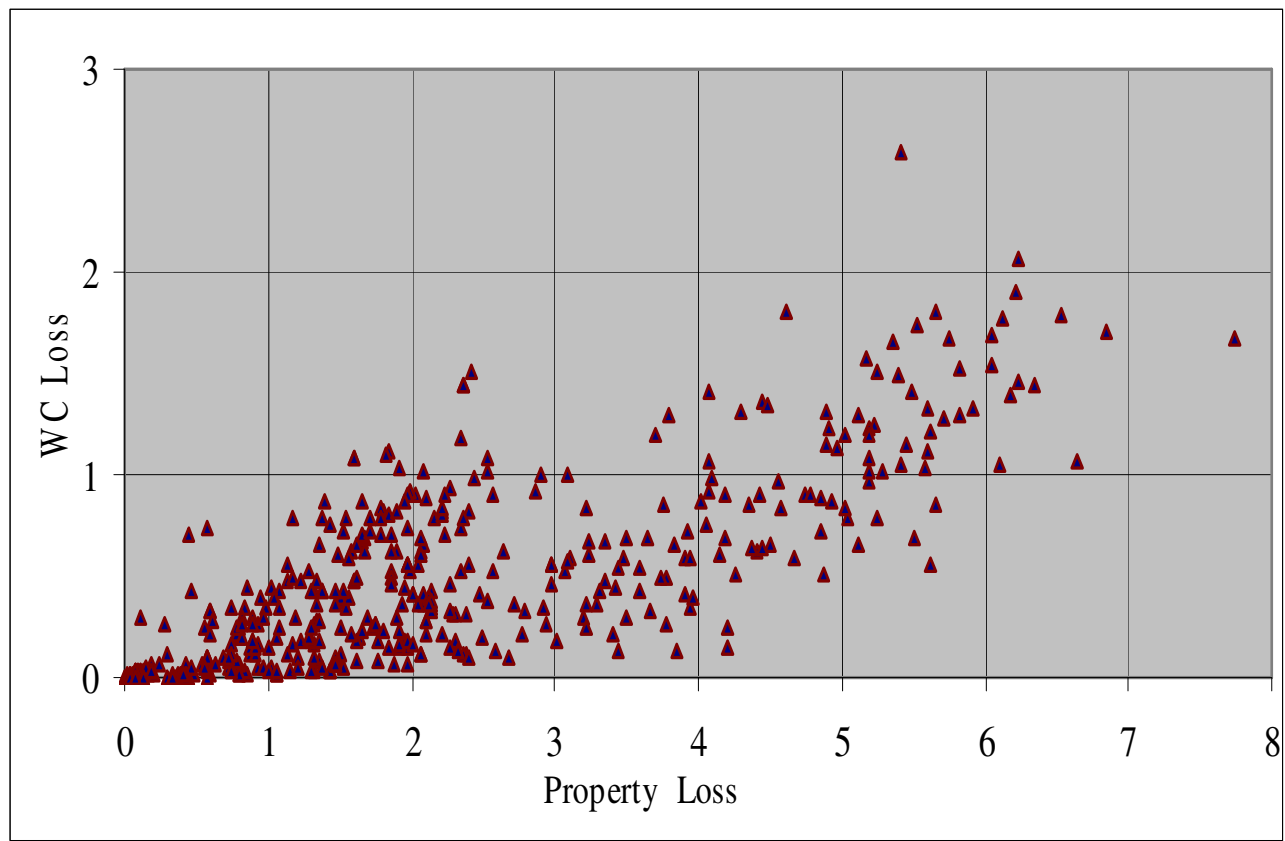

Figure 7. Projected Property Losses and Workers' Compensation (WC) Losses from Aircraft Attacks to 447 High-Rise Buildings in the United States (in \$ billion)

[Each triangle represents one specific high-rise building used in the simulation]

\section{Effect of Location and Attack Size on Loss Sharing under TRIA}

How would losses from foreign terrorist attacks on U.S. soil be distributed across the relevant affected parties? This question can be answered differently, depending on different risk-sharing scenarios that vary with respect to location, magnitude of damage and terrorism risk insurance take-up rate.

\section{Assumptions}

We make a number of assumptions to examine these losses. Because data are not available on individual insurer's terrorism exposure, we utilize market shares of insurers to allocate losses from a terrorist attack between the 451 largest insurers that comprise 97 percent of the market with respect to 2004 TRIA-line direct earned premiums (DEP) ${ }^{34}$. Market shares appear to be the most reasonable proxy for analyzing loss sharing across the affected parties. In addition, we separate property insurance lines from workers' compensation lines. In the case of property coverage we utilize premiums written for nationwide commercial coverage. With respect to workers' compensation (WC) coverage we have access to insurers' market shares in the relevant states and therefore allocate losses using these data ${ }^{35}$.

\footnotetext{
${ }^{34}$ Since data are not available on individual insurers' terrorism exposure, market share appears to be the most reasonable proxy for analyzing loss sharing across the affected parties.

${ }^{35}$ For each of the three states on which we focus our analysis, there are major competitive workers' compensation insurers: New York State Insurance Fund, State Compensation Insurance Fund of California and Texas Mutual Insurance Company. The State Compensation Insurance Fund of California covers half
} 
We first undertake a comparative analysis of loss distribution between the affected parties as we vary location, level of loss and take-up rate under a scenario in which the terrorist attacks take place in 2005 with TRIA in place. In this scenario, insurers will pay their entire loss up to their TRIA deductible (D: 15 percent of the TRIAline DEP in 2004) and then an additional 10 percent above D, with the federal government paying the other 90 percent $^{36}$. Under TRIA the federal government would levy a surcharge against all policyholders purchasing commercial insurance to recoup part of its payment within the total insurers' payments and the insurance industry retention ( $\$ 15$ billion in 2005) ("mandatory recoupment").

\section{Effect of Attack Location}

The effect on loss sharing of two 5-ton truck bomb attacks varies greatly depending on the location of the attack (Table 1). Under our simulation, we compare the total property loss ( $\$ 15$ billion) and workers' compensation loss ( $\$ 10$ billion) in three major cities (New York City for New York, Los Angeles for California, and Houston for Texas). We also assume that half of the property damage to commercial enterprises in the buildings is covered by either terrorism insurance or fire-following insurance, and that all the workers' compensation losses are covered by insurance. This scenario results in a $\$ 17.5$ billion in insured loss out of the $\$ 25$ billion total. A sensitivity analysis relative to the insurance take-up rate is undertaken later in this subsection.

Table 1. City Comparison of Simulated Scenario Involving five-ton Truck Bombs (\$25 billion in losses: 50 percent coverage for property;

100 percent coverage for workers' compensation [WC]); 2005 TRIA

\begin{tabular}{|c|c|c|c|c|c|}
\hline \multirow{2}{*}{\multicolumn{2}{|c|}{ 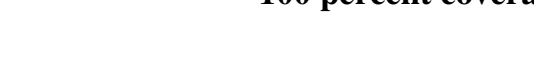 }} & \multirow{2}{*}{\multicolumn{4}{|c|}{ ss Shamino }} \\
\hline & & & & & \\
\hline $\begin{array}{c}\text { City } \\
\text { Comparison }\end{array}$ & $\begin{array}{c}\text { Not- } \\
\text { insured } 37\end{array}$ & $\begin{array}{c}\text { Total } \\
\text { insured }\end{array}$ & $\begin{array}{l}\text { Insurers' } \\
\text { Payments }\end{array}$ & $\begin{array}{c}\text { All } \\
\text { Policyholders }^{38}\end{array}$ & $\begin{array}{c}\text { Final } \\
\text { Government } \\
\text { Taxpayers } \\
\end{array}$ \\
\hline New York, NY & $\$ 7.5 \mathrm{bn}$ & $\$ 17.5 \mathrm{bn}$ & \$13.27bn & $\$ 1.73 \mathrm{bn}$ & $\$ 2.5 \mathrm{bn}$ \\
\hline \multicolumn{3}{|c|}{ Insured loss sharing } & $76 \%$ & $10 \%$ & $14 \%$ \\
\hline Los Angeles, CA & $\$ 7.5 \mathrm{bn}$ & $\$ 17.5 \mathrm{bn}$ & \$13.1bn & $\$ 1.9 \mathrm{bn}$ & $\$ 2.5 \mathrm{bn}$ \\
\hline \multicolumn{3}{|c|}{ Insured loss sharing } & $75 \%$ & $11 \%$ & $14 \%$ \\
\hline Houston, TX & $\$ 7.5 \mathrm{bn}$ & $\$ 17.5 \mathrm{bn}$ & $\$ 14.5 b n$ & $\$ 0.5 \mathrm{bn}$ & $\$ 2.5 \mathrm{bn}$ \\
\hline \multicolumn{3}{|c|}{ Insured loss sharing } & $83 \%$ & $3 \%$ & $14 \%$ \\
\hline
\end{tabular}

of workers' compensation lines in the state while the major insurers in New York and Texas cover 40 percent and 20 percent respectively of the total WC coverage in their states.

${ }^{36} \mathrm{We}$ assume that insurers have not purchased reinsurance. If they have, then the amount of their loss would be somewhat reduced. We assume a zero deductible for the policyholder on their terrorism insurance policy. This assumption simplifies the analysis but does not affect the qualitative results.

${ }_{37}^{37}$ Retained by policyholders who suffered the losses but were not covered against terrorism.

${ }^{38}$ The federal government recoups the $90 \%$ portion of the insured loss it initially paid above insurers' payments up to an industry aggregate of $\$ 15$ billion in 2005 (see Section 2 on TRIA design). 
Under this scenario, the insurers and policyholders will absorb $\$ 15$ billion of the $\$ 17.5$ billion insured loss in each of the three cities. However, the distribution of payments between insurers and all policyholders differs across metropolitan areas (due to different workers compensation market shares). In both New York and California, two or three large insurers provide a very large portion of workers' compensation coverage for the entire state -- they will have a much higher loss relative to their TRIA deductible than workers' compensation insurers in Texas, where there is less concentration of coverage in one company. Hence, the federal government will initially pay more in New York and California (the 90 percent portion above the deductible of the few key workers' compensation insurers), and then recoup part of that payment against all policyholders. In all three cities, the federal government covers $\$ 2.5$ billion of the loss, which is shared by all U.S. taxpayers ${ }^{39}$.

\section{Effect of Size of Loss}

Changing the size of the loss from $\$ 0.5$ billion to $\$ 100$ billion affects the distribution of payments (Table 2). We detail the effect in one specific metropolitan area (New York, NY), using the same assumptions as in the previous section: half of the property damage to commercial enterprises in the buildings are covered by either terrorism insurance or by fire-following insurance, and all the workers' compensation losses are covered by insurance.

Table 2. Impact of Varying Losses from 5-ton Truck Bomb Attacks on New York City (50 percent insurance coverage for property;

100 percent coverage for workers' compensation [WC]); 2005 TRIA

\begin{tabular}{|c|c|c|c|c|c|}
\hline \multirow[b]{2}{*}{$\begin{array}{c}\underline{\text { Loss }} \\
\underline{\text { Scenarios }}\end{array}$} & \multirow[b]{2}{*}{$\begin{array}{c}\text { Not- } \\
\text { insured }^{40}\end{array}$} & \multicolumn{4}{|c|}{ Loss Sharing } \\
\hline & & $\begin{array}{c}\text { Total } \\
\text { insured }\end{array}$ & $\begin{array}{l}\text { Insurers' } \\
\text { Payments }\end{array}$ & $\begin{array}{c}\text { All } \\
\text { Policyholders }^{41}\end{array}$ & $\begin{array}{c}\text { Final } \\
\text { Goverment } \\
\text { Taxpayers }\end{array}$ \\
\hline $\begin{array}{l}\text { Total: } \$ \mathbf{0 . 5 b n} \\
\text { Property: } \$ 0.25 \mathrm{bn} \\
\text { WC: } \$ 0.25 \mathrm{bn}\end{array}$ & $\$ 125 \mathrm{mi}$ & $\$ 375 \mathrm{mi}$ & $\$ 375 \mathrm{mi}$ & $\$ 0$ & $\$ 0$ \\
\hline \multicolumn{3}{|c|}{ Insured loss sharing } & $100 \%$ & $0 \%$ & $0 \%$ \\
\hline $\begin{array}{l}\text { Total: } \$ 5 \mathrm{bn} \\
\text { Property: } \$ 2.5 \mathrm{bn} \\
\text { WC: } \$ 2.5 \mathrm{bn}\end{array}$ & $\$ 1.25 \mathrm{bn}$ & $\$ 3.75 b n$ & $\$ 2.97 \mathrm{bn}$ & $\$ 780 \mathrm{mi}$ & $0 \$$ \\
\hline \multicolumn{3}{|c|}{ Insured loss sharing } & $79.2 \%$ & $20.8 \%$ & $0 \%$ \\
\hline $\begin{array}{l}\text { Total: \$15bn } \\
\text { Property: \$9bn } \\
\text { WC: } \$ 6 \mathrm{bn}\end{array}$ & $\$ 4.5 \mathrm{bn}$ & $\$ 10.5 \mathrm{bn}$ & $\$ 8.23 \mathrm{bn}$ & $\$ 2.27 \mathrm{bn}$ & $\$ 0$ \\
\hline \multicolumn{3}{|c|}{ Insured loss sharing } & $78.3 \%$ & $21.7 \%$ & $0 \%$ \\
\hline
\end{tabular}

\footnotetext{
39 The U.S. Department of Treasury has the authority to collect the $\$ 2.5$ billion through surcharges if it elects to do so, but here we only allow a recoupment for losses between the insurer's payments and the $\$ 15$ billion market retention in 2005 .

${ }^{40}$ Retained by policyholders who suffered the losses but were not covered against terrorism.

${ }^{41}$ The federal government is assumed to recoup the portion of insured loss it initially paid above insurers' payments up to an industry aggregate of \$15 billion in 2005 .
} 


\begin{tabular}{|c|c|c|c|c|c|}
\hline $\begin{array}{l}\text { Total: } \mathbf{\text { 25bn }} \\
\text { Property: } \$ 15 \mathrm{bn} \\
\text { WC: } \$ 10 \mathrm{bn}\end{array}$ & $\$ 7.5 \mathrm{bn}$ & $\$ 17.5 \mathrm{bn}$ & \$13.27bn & $\$ 1.73 b n$ & $\$ 2.5 \mathrm{bn}$ \\
\hline \multicolumn{3}{|c|}{ Insured loss sharing } & $75.9 \%$ & $9.9 \%$ & $14.2 \%$ \\
\hline $\begin{array}{l}\text { Total: } \$ 40 \mathrm{bn} \\
\text { Property: } \$ 28 \mathrm{bn} \\
\text { WC: } \$ 12 \mathrm{bn}\end{array}$ & \$14bn & $\$ 26 b n$ & $\$ 20.6 \mathrm{bn}$ & $\$ 0$ & $\$ 5.4 \mathrm{bn}$ \\
\hline \multicolumn{3}{|c|}{ Insured loss sharing } & $79.2 \%$ & $0 \%$ & $20.8 \%$ \\
\hline $\begin{array}{l}\text { Total: } \$ 40 \mathrm{bn} \\
\text { Property: } \$ 12 \mathrm{bn} \\
\text { WC: } \$ 28 \mathrm{bn}\end{array}$ & $\$ 6 \mathrm{bn}$ & \$34bn & $\$ 18.7 \mathrm{bn}$ & $\$ 0$ & $\$ 15.3 \mathrm{bn}$ \\
\hline \multicolumn{3}{|c|}{ Insured loss sharing } & $55 \%$ & $0 \%$ & $45 \%$ \\
\hline $\begin{array}{l}\text { Total: } \$ 100 \mathrm{bn} \\
\text { Property: } \$ 50 \mathrm{bn} \\
\text { WC: } \$ 50 \mathrm{bn}\end{array}$ & $\$ 25 \mathrm{bn}$ & \$75bn & \$34.1bn & $\$ 0$ & $\$ 40.9 \mathrm{bn}^{42}$ \\
\hline \multicolumn{3}{|c|}{ Insured loss sharing } & $45.5 \%$ & $0 \%$ & $54.5 \%$ \\
\hline
\end{tabular}

The figures reveal that, if losses from terrorist attacks do not exceed $\$ 15$ billion, the insurance companies and policyholders will bear all of the losses. We considered two cases for which the total loss is $\$ 40$ billion. In Case 1, property loss is $\$ 28$ billion and workers' compensation is $\$ 12$ billion. In Case 2, the dollar figures are reversed: property loss is $\$ 12$ billion and workers' compensation is $\$ 28$ billion. Even if the total loss is the same, the loss sharing differs considerably between these two cases. While taxpayers would end up paying $\$ 5.4$ billion in Case 1 , they would pay $\$ 15.3$ billion in Case 2 . The difference is due to both the level of insured loss and the distribution of loss among insurers who have different deductibles under TRIA. In other words, a $\$ 1$ billion loss due to property damage is shared differently than a $\$ 1$ billion loss of workers' compensation, because the insurers are different. If the terrorist attacks lead to losses of $\$ 100$ billion, under a scenario in which losses are half property, half workers' compensation, then the U.S. taxpayers will bear 54.5 percent of the total insured losses.

\section{Increased Burden on Insurers and Commercial Enterprises (covered or not against terrorism) in 2006 and 2007}

How are these results likely to be modified this year and in 2007? There is no definitive answer to that question now. The design of the program requires one to specify direct earned premium under TRIEA lines collected the previous year (i.e., 2005), and these data will not be available before mid-2006.

Some have use the "total industry DEP/deductible" as a proxy to measure how terrorism losses would be shared between insurers, all policyholders and taxpayers. However, our data analyses have shown that the loss shares differed very significantly depending on whether one considered such an-incorrect-aggregate approach or the more

\footnotetext{
${ }^{42}$ Including $\$ 18.3$ billion that would represent the $90 \%$ federal payment above the New York Insurance Fund's TRIA deductible.
} 
granular insurer-based one on which TRIEA is really based ${ }^{43}$. What can be done at this time is to understand under in what directions loss sharing is likely to evolve under the revised design of the terrorism insurance program.

\section{Effect of the Increased Industry Market Retention on Loss Sharing}

While most of the debate has been focused on the increase in insurer deductible, the major change in TRIEA is the increase of insurance industry retention from $\$ 15$ to $\$ 25$ billion in 2006. In Table 3, we utilize the results of the analyses summarized in Table 2 but modify the retention level to reflect this change (results are indicated in [ ] ).

For total insured losses under $\$ 15$ billion there is, of course, no difference. For the $\$ 25$ billion loss scenario, however, the $\$ 2.5$ billion that would have been paid by taxpayers in 2005 is now paid by policyholders. The difference is even more significant for the two $\$ 40$ billion scenarios: commercial policyholders, whether they are covered against terrorism or not, pay $\$ 4.4$ billion and $\$ 6.3$ billion respectively. For the same $\$ 100$ billion scenario than the one used before, there is no difference because insurers already pay $\$ 34.1$ billion in claims, which is above the $\$ 25$ billion retention -- in that case there is no mandatory recoupment by the federal government.

Table 3. Impact of Varying Losses from 5-ton Truck Bomb Attacks on New York City $50 \%$ Insurance for Property Coverage; 100\% Insurance for workers' compensation; 2005 ; $\$ 15$ billion industry market retention [\$25 billion industry market retention]

\begin{tabular}{|c|c|c|c|c|c|}
\hline \multirow{3}{*}{$\underline{\underline{\text { Loss }}} \underline{\underline{\text { Scenarios }}}$} & \multirow{3}{*}{$\begin{array}{c}\text { Not- }^{44} \\
\text { insured }^{44}\end{array}$} & \multirow{2}{*}{\multicolumn{4}{|c|}{ Loss Sharing: }} \\
\hline & & & & & \\
\hline & & $\begin{array}{c}\text { Total } \\
\text { insured }\end{array}$ & $\begin{array}{l}\text { Insurers' } \\
\text { Payments }\end{array}$ & $\begin{array}{c}\text { All } \\
\text { Policyholders }^{45}\end{array}$ & $\begin{array}{c}\text { Final } \\
\text { Goverment } \\
\text { Taxpayers }\end{array}$ \\
\hline $\begin{array}{l}\text { Total: } \$ \mathbf{0 . 5 b n} \\
\text { Property: } \$ 0.25 \mathrm{bn} \\
\text { WC: } \$ 0.25 \mathrm{bn}\end{array}$ & $\$ 125 \mathrm{mi}$ & $\$ 375 \mathrm{mi}$ & $\begin{array}{c}\$ 375 \mathrm{mi} \\
{[\$ 375 \mathrm{mi}]}\end{array}$ & $\begin{array}{c}\$ 0 \\
{[\$ 0]}\end{array}$ & $\begin{array}{c}\$ 0 \\
{[\$ 0]}\end{array}$ \\
\hline \multicolumn{3}{|c|}{ Insured loss sharing } & $100 \%$ & $0 \%$ & $0 \%$ \\
\hline $\begin{array}{l}\text { Total: } \$ 5 \mathrm{bn} \\
\text { Property: } \$ 2.5 \mathrm{bn} \\
\text { WC: } \$ 2.5 \mathrm{bn}\end{array}$ & $\$ 1.25 \mathrm{bn}$ & $\$ 3.75 b n$ & $\begin{array}{c}\$ 2.97 \mathrm{bn} \\
{[\$ 2.97 \mathrm{bn}]}\end{array}$ & $\begin{array}{c}\$ 780 \mathrm{mi} \\
{[\$ 780 \mathrm{mi}]}\end{array}$ & $\begin{array}{c}\$ 0 \\
{[\$ 0]}\end{array}$ \\
\hline \multicolumn{3}{|c|}{ Insured loss sharing } & $79.2 \%$ & $20.8 \%$ & $0 \%$ \\
\hline $\begin{array}{l}\text { Total: } \$ 15 b n \\
\text { Property: } \$ 9 b n \\
\text { WC: \$6bn }\end{array}$ & $\$ 4.5 b n$ & $\$ 10.5 b n$ & $\begin{array}{c}\$ 8.23 \mathrm{bn} \\
{[\$ 8.23 \mathrm{bn}]}\end{array}$ & $\begin{array}{c}\$ 2.27 \mathrm{bn} \\
{[\$ 2.27 \mathrm{bn}]}\end{array}$ & $\begin{array}{c}\$ 0 \\
{[\$ 0]}\end{array}$ \\
\hline \multicolumn{3}{|c|}{ Insured loss sharing } & $78.3 \%$ & $21.7 \%$ & $0 \%$ \\
\hline $\begin{array}{l}\text { Total: \$25bn } \\
\text { Property: \$15bn } \\
\text { WC: } \$ 10 \mathrm{bn}\end{array}$ & $\$ 7.5 \mathrm{bn}$ & $\$ 17.5 b n$ & $\begin{array}{c}\$ 13.27 \mathrm{bn} \\
{[\$ 13.27 \mathrm{bn}]}\end{array}$ & $\begin{array}{c}\$ 1.73 \mathrm{bn} \\
{[\$ 4.23 \mathrm{bn}]}\end{array}$ & $\begin{array}{c}\$ 2.5 \mathrm{bn} \\
{[\$ 0]}\end{array}$ \\
\hline \multicolumn{3}{|c|}{ Insured loss sharing } & $75.9 \%$ & $9.9 \%$ & $14.2 \%$ \\
\hline & & & $75.9 \%$ & $24.1 \%$ & $0 \%$ \\
\hline
\end{tabular}

\footnotetext{
${ }^{43}$ While still imperfect because we consider each insurer's market share in the location where we simulate the attack, not the real coverage provided by that insurer for the specific target.

${ }^{44}$ Retained by policyholders who suffered the losses but were not covered against terrorism.

45 The federal government is assumed to recoup the portion of insured loss it initially paid above insurers' payments up to an industry aggregate of \$15 billion in 2005 .
} 


\begin{tabular}{|c|c|c|c|c|c|}
\hline $\begin{array}{l}\text { Total: } \$ 40 \mathrm{bn} \\
\text { Property: } \$ 28 \mathrm{bn} \\
\text { WC: } \$ 12 \mathrm{bn}\end{array}$ & \$14bn & \$26bn & $\begin{array}{c}\$ 20.6 \mathrm{bn} \\
\text { [20.6bn] }\end{array}$ & $\begin{array}{c}\$ 0 \\
{[\$ 4.4 \mathrm{bn}]}\end{array}$ & $\begin{array}{c}\$ 5.4 \mathrm{bn} \\
{[\$ 1.0 \mathrm{bn}]}\end{array}$ \\
\hline \multicolumn{3}{|c|}{ Insured loss sharing } & $79.2 \%$ & $0 \%$ & $20.8 \%$ \\
\hline & & & $79.2 \%$ & $16.9 \%$ & $3.9 \%]$ \\
\hline $\begin{array}{l}\text { Total: } \$ 40 \mathrm{bn} \\
\text { Property: } \$ 12 \mathrm{bn} \\
\text { WC: } \$ 28 \mathrm{bn}\end{array}$ & $\$ 6 \mathrm{bn}$ & $\$ 34 \mathrm{bn}$ & $\begin{array}{c}\$ 18.7 \mathrm{bn} \\
{[\$ 18.7 \mathrm{bn}]}\end{array}$ & $\begin{array}{c}\$ 0 \\
{[\$ 6.3 \mathrm{bn}]}\end{array}$ & $\begin{array}{l}\$ 15.3 \mathrm{bn} \\
{[\$ 9 \mathrm{bn}]}\end{array}$ \\
\hline \multirow{2}{*}{\multicolumn{3}{|c|}{ Insured loss sharing }} & $55 \%$ & $0 \%$ & $45 \%$ \\
\hline & & & {$[55 \%]$} & {$[18.5 \%]$} & {$[26.5 \%]$} \\
\hline $\begin{array}{l}\text { Total: } \$ 100 \mathrm{bn} \\
\text { Property: } \$ 50 \mathrm{bn} \\
\text { WC: } \$ 50 \mathrm{bn}\end{array}$ & $\$ 25 \mathrm{bn}$ & $\$ 75 b n$ & $\begin{array}{c}\$ 34.1 \mathrm{bn} \\
{[\$ 34.1 \mathrm{bn}]}\end{array}$ & $\begin{array}{c}\$ 0 \\
{[\$ 0]}\end{array}$ & $\begin{array}{l}\$ 40.9 \mathrm{bn}^{46} \\
{[\$ 40.9 \mathrm{bn}]}\end{array}$ \\
\hline \multicolumn{3}{|c|}{ Insured loss sharing } & $45.5 \%$ & $0 \%$ & $54.5 \%$ \\
\hline
\end{tabular}

\section{Effect of the Increased Deductible and Market Conditions}

As discussed earlier, TRIEA increases the insurer deductible, as a percentage of the TRIA-line DEP in the previous year, from 15 percent in 2005 to 17.5 percent in 2006, and to 20 percent in 2007. While this represents a difference in 2.5 point of percentage each year, this translates into a 17 percent increase in 2006 and another 14 percent increase in 2007 (in absolute value). Between 2005 and 2007, for a given DEP level, there will be a 33 percent increase in the insurer's deductible under TRIEA.

The increased insurer deductible is affected by market conditions as well, if one expects TRIAE-line premiums to evolve over time. For example, the total TRIA-line premiums for our 451-insurers sample evolved as follows: $\$ 170.9$ billion in 2002, $\$ 197.2$ billion in 2003 (a 17 percent increase from the previous year), and $\$ 210.6$ billion in 2004 (a 7 percent increase from 2003). After the 2004 and 2005 hurricane seasons, it would not be surprising the see the market hardening so that a 10 to 15 percent annual increase in TRIEA-line premiums for 2005 and 2006 appears to be a reasonable assumption.

Suppose now that the portfolio of a representative insurer $\mathrm{X}$ follows the same evolution of the aggregate sample. If annual TRIA-line DEP in 2004 of insurer X were $\$ 100$ million then its terrorism coverage deductible under TRIA for 2005 would have been $\$ 15$ million. Assuming a 13 percent increase in TRIE-line DEP in 2005, then insurer X's deductible under TRIEA for 2006 would be $\$ 19.775$ million (i.e. .175 (\$113 million)). This represents a 31.8 percent increase in its terrorism deductible from the previous year in absolute value. If premium increases follow a similar pattern between 2005 and 2006, then insurer X's deductible under TRIEA for 2007 would be $\$ 25.54$ million (i.e. .20 (\$127.69 million)).

This reflects a 70 percent increase over its deductible in 2005. The impact on the precise amount of terrorism loss sharing can be determined after data from 2005 becomes available. What is clear is that insurers and policyholders will pay a much greater loss

\footnotetext{
${ }^{46}$ Including $\$ 18.3$ billion that would represent the $90 \%$ federal payment above the New York Insurance Fund's TRIA deductible.
} 
share in 2006 and 2007 than under the 2005-attack scenario due to the higher deductible and higher market retention and hence the general taxpayer will incur a smaller portion of the loss.

\section{Private Efficiency, Public Vulnerability: Will Insurers Strategize if the Current Program is Made Permanent?}

We can use the scenario methodology to analyze the question as to how insurers will react if the program is made permanent in its current form. Will insurers' exposure to terrorism losses change from what it currently is under TRIEA and, if so, what would be the impact on loss sharing between the affected parties following a large-scale terrorist attack on U.S. soil?

To examine this question, we assume that TRIEA officially becomes a permanent program with the insurer's deductible at 17.5 percent of their TRIEA-line DEP from the previous year. All insurers know that they will have to pay for all losses they incur below this deductible $(D)$ and 10 percent of the loss above it, the remaining $90 \%$ eventually paid by other parties (taxpayers, policyholders). An insurer with a very low deductible/surplus ratio would have a rationale for this insurer to take advantage of the small percentage it will have to absorb if its loss exceeds the TRIA deductible. Any insurer with a low deductible/surplus $(D / S)$ ratio would have an economic incentive to write a large number of policies in a concentrated area subject to a terrorist attack (e.g. Times Square, Wall Street area) due to the positive correlation in these losses. In other words, the insurer knows that if one of these buildings is damaged or destroyed, the surrounding ones are also likely to suffer severe damage.

\section{Determining Terrorism Coverage Using an " $E$ * Gaming Strategy"}

To examine how the aggregate exposure/surplus ratio affects the amount of coverage an insurer will want to provide if TRIEA is extended indefinitely, we use the following notation:

$$
\begin{aligned}
& E^{*}=\text { maximum insured terrorism exposure (i.e. } \text { worst case scenario) } \\
& E=\text { actual dollar claims incurred by an insurer from a worst case scenario } \\
& D E P=\text { direct earned premiums written for TRIA lines of coverage } \\
& D=a D E P=\text { TRIA/TRIEA deductible determined by the percentage a (e.g. } \\
& 2006) \\
& \mathrm{S}=\text { current surplus } \\
& \mathrm{X}=\mathrm{E} / \mathrm{S}=\text { aggregate exposure for terrorism/surplus ratio } \\
& \mathrm{Y}=\mathrm{D} / \mathrm{S}=\text { deductible/surplus ratio }
\end{aligned}
$$$$
\mathrm{D}=\mathrm{aDEP}=\mathrm{TRIA} / \mathrm{TRIEA} \text { deductible determined by the percentage } \mathrm{a}(\text { e.g. } \mathrm{a}=17.5 \% \text { in }
$$

Given the difficulties in estimating the probability of a terrorist attack, rating agencies focus on deterministic scenarios in evaluating an insurer's credit rating. We focus our estimates on insured losses from a five-to-six truck bomb scenario in determining the maximum exposure an insurer will be willing to accept. If an insurer 
experiences insured losses of $E^{*}$, it determines its dollar claims $(E)$ with one of two equations:

$$
\begin{aligned}
& \mathrm{E}=\mathrm{E}^{*} \quad \text { if } \mathrm{E}^{*} \leq \mathrm{D} \\
& \mathrm{E}=\mathrm{D}+.1\left(\mathrm{E}^{*}-\mathrm{D}\right) \quad \text { if } \mathrm{E}^{*}>\mathrm{D}
\end{aligned}
$$

A possible line of analysis would be to suppose that the maximum amount of terrorism exposure $\left(E^{*}\right)$ that an insurer wants to write is determined by a desired aggregate exposure/surplus $(E / S)$ ratio given by $x$ (e.g. $x=10 \%)$. To determine the value of $E^{*}$ the insurer first computes $D / S=y$ and compares the value of $y$ with $x$.

- If $y \geq x$, the insurer knows that its claims are determined by the first equation (1) (i.e. $\mathrm{E}=\mathrm{E}^{*}$ ), because it is responsible for the entire loss on its own given that $D / S>x$. The insurer thus sets $E^{*}=x S$.

- On the other hand, if $y<x$, the insurer knows that its claims are determined by the second equation (2), and the government will cover 90 percent of the insured loss above its TRIA deductible, given the federal backstop provision of TRIA. In this case, the insurer computes $E / S=D / S+.1\left(E^{*} / S-D / S\right)$ which can be written as $x=y+.1\left(E^{*} / S-y\right)$ or $E^{*}=(10 x-9 y) S$

To illustrate this strategy with a simple numerical example, we assign the values of $D=10, S=200, y=.05$ and $x=.10$ Since $y<x$, E* is determined by (3) as follows:

$$
E^{*}=(1-0.45) 200=110
$$

If an insurer were responsible for the entire loss, then $E=E^{*}$ for all values of $E^{*}$ so that $E^{*}=x S$. For this example, $E^{*}=.10(200)=20$, which is considerably lower than the scenario in which the insurer is responsible for only 10 percent of the loss, as it was under TRIA and still is under TRIEA in 2006.

To examine the impact of a permanent TRIA-like program on the amount of terrorism coverage written by insurers, we assume that each insurer is concerned with maintaining an aggregate exposure from deterministic scenarios at 10 percent of its surplus $(S)^{47} . E$, then, is be the ultimate exposure of the insurer; that is, what it will pay after sharing part of the loss with other parties.

$E^{*}$ represents the aggregate exposure that an insurer is willing to risk if it is responsible for ten percent of the loss above $D=15$ percent (e.g., the arrangement under TRIA in 2005) and it wants to set a value of $E / S=D+.1\left(E^{*}-D\right)=10 \%$.

We define an $E^{*}$ gaming strategy as the decision by an insurer to increase significantly the amount of coverage it provides in order to take advantage of the $90 \%$ risk-sharing arrangement with the government, and at the same time to collect a significant amount of terrorism insurance premiums ${ }^{48}$.

We focus on the locations where a large terrorism loss is more likely. To make the data analysis manageable, we have limited our sample of insurers to those who already

\footnotetext{
${ }^{47}$ This assumption represents a very prudent behavior. Indeed, 17 of the top 30 insurers already have a $D / S$ ratio equal or higher than 10 percent in 2005.
} 
provide the largest terrorism coverage in urban areas. We focused on the top 30 insurers based on TRIA-line direct earned premiums in 2004 and then eliminated the 7 companies who are small business and personal lines writers. This group of 23 large insurers actually accounts for about two-thirds of the TRIA-lines direct earned premiums. For the sake of simplicity, we then make the assumption that these 23 insurers cover 100 percent of the insured losses in the city we consider. We then analyze how losses would be shared under TRIA and compare this with a design of a "permanent TRIA."

For each insurer, we can determine its aggregate terrorism coverage in urban areas. For insurers with a $D / S$ ratio greater than 10 percent, insurers limit their exposure to 10 percent of their surplus $\left(E^{*}=E\right)$. Those with $D / S$ less than 10 percent could offer much more coverage than under TRIA, particularly those with very small $D / S$ due to a large surplus $\left(E^{*}>E\right)$. Figure 8 depicts the difference that fixing a threshold of $E / S=10$ percent would have on insurers' decisions regarding how much terrorism coverage to offer, depending on whether the insurer had a $D / S$ ration higher than 10 percent (Insurer (a); left part of the graph) and those with $D / S$ less than 10 percent (Insurer (b); right part of the graph). In both cases, there are two bars. The solid gray one on the left indicates the $D / S$ ratio of the insurer in 2005 , the one made up of oblique lines on the right indicates exposure based on the constraint that $E / S=10$ percent.

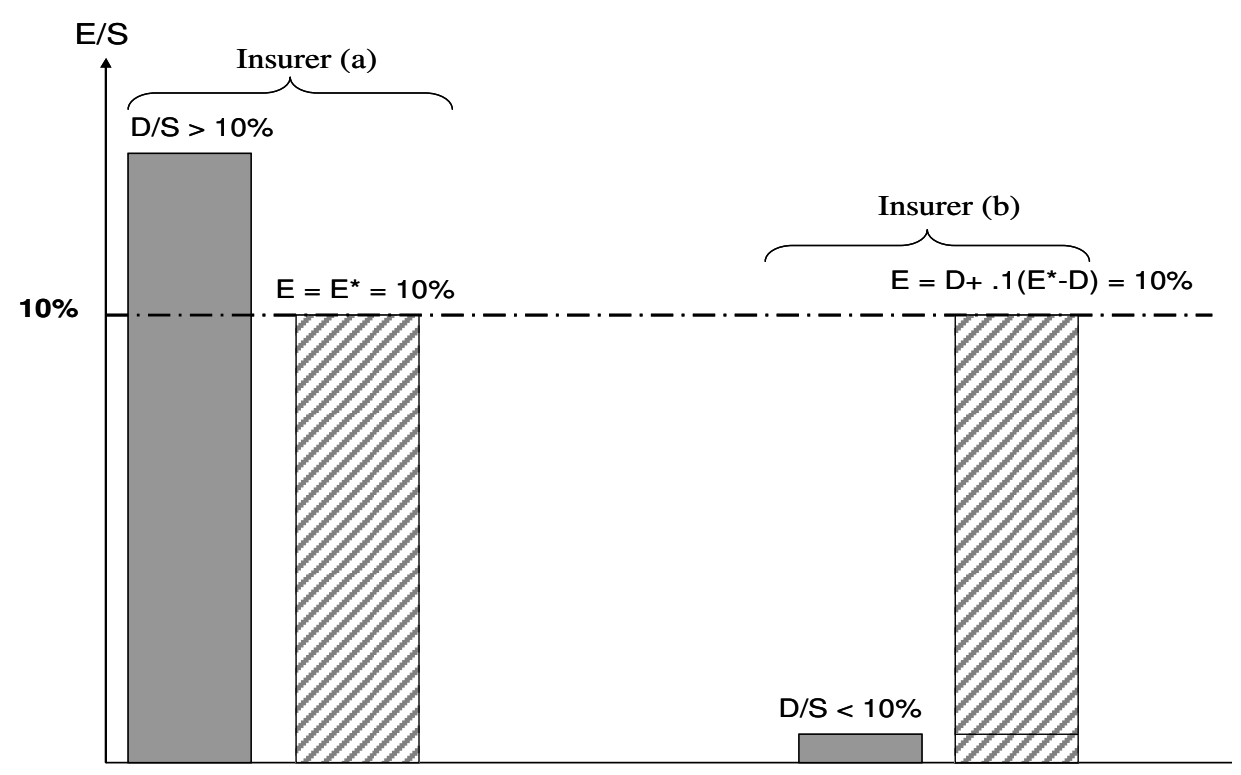

Figure 8. Insurer's Exposure Limited to $10 \%$ of Its Surplus

The aggregate exposure for each of these two types of insurer is depicted in Figure 9. An insurer with considerable business in non-TRIA lines such that its surplus is high but its deductible is quite low will take advantage of the structure of TRIA's program (if it is made permanent) by increasing its aggregate exposure considerably from the current level, up to $E^{*}$. For example, insurer (b) on Figure 9 will only pay 10 percent of any loss above its deductible ( $D$; the portion represented by oblique lines) with the other 90 percent paid by taxpayers and possibly all policyholders under the federal government's recoupment arrangement under TRIA (the area represented by horizontal lines). 


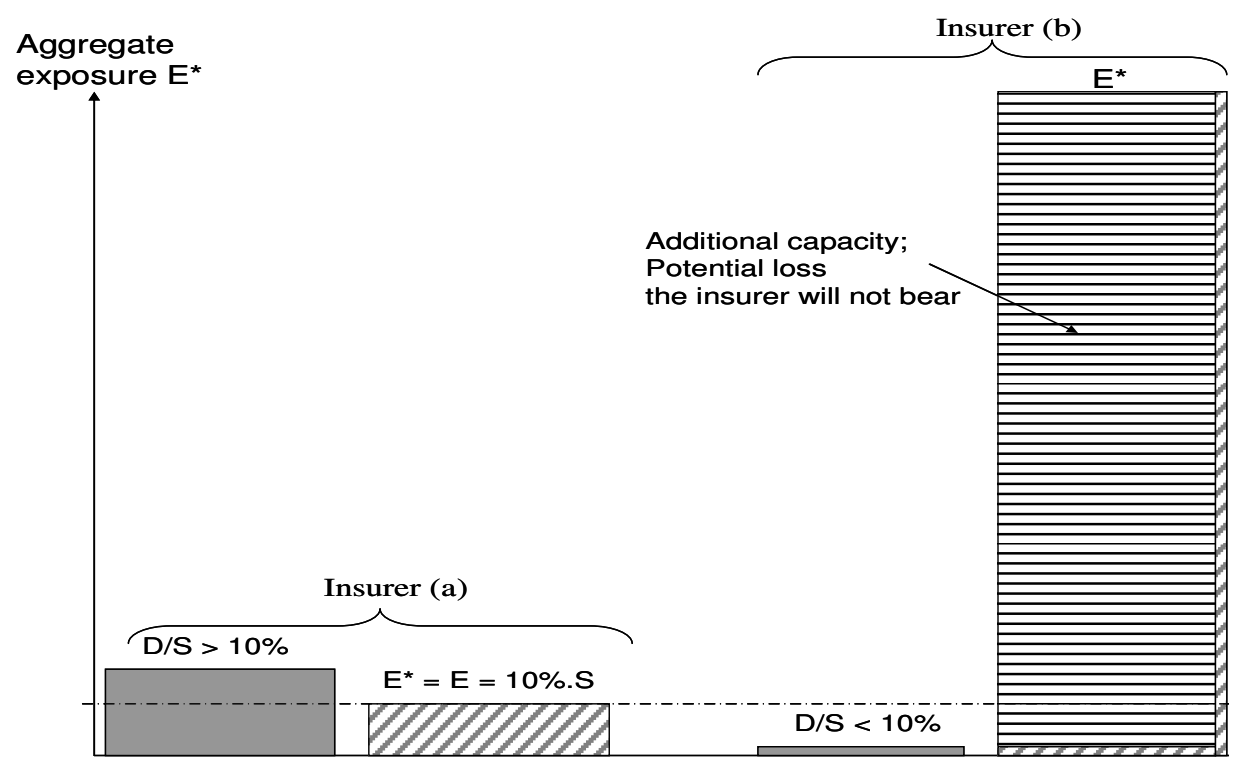

Figure 9. Aggregate Exposure of Insured Losses; Additional Capacity Provided by Insurers with $\mathrm{D} / \mathrm{S}<10 \%$

An important difference from the analyses undertaken in the previous section of the paper is that market share is now based on each insurer's $E^{*}$. In this case, we assume that $E^{*}$ is composed of both property and workers' compensation coverage. As a result the market shares of insurers providing terrorism coverage would be quite different if a TRIA-like program were made permanent. In particular, the New York State Insurance Fund would likely not be the major provider of workers' compensation coverage anymore, as its surplus is much lower than other large insurers; the company is therefore constrained in how much terrorism insurance it will be willing to write.

Using $E^{*}$, one can then determine how the coverage from a terrorist attack would be spread across insurers. Because insurers with low $D / S$ ratios are willing to write considerably more property coverage at relatively low prices in metropolitan areas if TRIA is made permanent, all commercial enterprises will expect to be insured against property losses (we assume a 100 percent take-up rate) ${ }^{49}$.

\section{Allocation of Losses Across Affected Stakeholders}

As mentioned earlier, data for 2006 are not available yet, so we provide the analysis by making the design of TRIA-2005 permanent. We discuss in this section who pays for the losses under TRIA in 2005, and should TRIA be made permanent, for two scenarios in New York City: a \$25 billion and \$100 billion terrorist attack using five-ton

\footnotetext{
${ }^{49}$ It is unclear how terrorism insurance will be priced under this scenario. Insurers with low $D / S$ ratios competing for business in urban areas will have an economic incentive to reduce their price as they expand their coverage, because they know they will be only responsible for 10 percent of any loss greater then $D$-something an insurer with more limited surplus cannot do. As a result, the major providers of coverage will be winnowed down to only a few insurers.
} 
truck bombs. Under TRIA in 2005, the allocation of losses is based on each insurer's market share of total property-casualty premiums for commercial coverage, and insurers are assumed not to be using an $E^{*}$ strategy. The now 100 percent take-up rate when TRIA is made permanent results in a shift of non-insured losses $(\$ 7.5$ billion and $\$ 25$ billion, respectively) to either all the policyholders or the government/taxpayers (Table 4). On first glance it seems counterintuitive that insurers will pay less for terrorism losses when their take-up rate is 100 percent rather than 50 percent. The reason is that insurers with low $D / S$ ratios will increase their exposure very significantly, as shown in Figure 9. Following a terrorist attack, these few insurers will be initially responsible for the largest part of the losses.

Under TRIA in 2005, these losses would have been spread over a much larger number of insurers, who collectively would have absorbed more of the loss because it would fall below their values of $D$. In other words, under a permanent TRIA program these few insurers will end up paying a very limited portion of their exposure (they actually pay $E$ not $E^{*}$ ), while the federal government will cover 90 percent of the loss above their $D$ levels. As with the other analyses, we assume that the federal government will pay for any losses above the $\$ 15$ billion industry market retention without recoupment of any of their expenditures under the TRIA federal backstop provision.

Consider the insurance scenario with a $\$ 25$ billion loss. Because the total loss will increase from $\$ 17.5$ billion (with a 50 percent take-up rate) to $\$ 25$ billion (with a 100 percent take-up rate), the general taxpayer's share of the loss will increase from $\$ 2.5$ billion to $\$ 10$ billion - that is a 300 percent increase from the current TRIA program. The difference between the $\$ 15$ billion insurance industry retention and insurers' payments of $\$ 13.3$ billion will be charged against all policyholders who will experience a 288 percent increase in payments. The difference in market shares induced by a few insurers playing an $E^{*}$ strategy would result in a 37 percent decrease in insurance industry payments, even if all losses caused by the attacks are now covered (Table 4).

In the more extreme case of a $\$ 100$ billion loss, when some insurers decide to significantly increase their aggregate exposure after learning that TRIA is renewed indefinitely, the insurance industry would pay considerably less in claims even though the take-up rate on property coverage is assumed to be 100 percent. More specifically, due to their higher exposures when TRIA is extended indefinitely, the insurers will receive a larger subsidy from the federal government than they would under TRIA today. Furthermore the insurance industry loss with either a 50 percent or 100 percent take-up rate is greater than the $\$ 15$ billion market retention rate. We assume that taxpayers cover the loss above this amount so there will be no recoupment of the subsidy by the federal government and the commercial policyholders will not be taxed at all. Hence the insurers actually pay less when total insured losses are $\$ 100$ billion than when they are $\$ 75$ billion (Table 4). Indeed, the larger total insured loss due to the increased coverage amount is passed on to the U.S. taxpayers who now absorb $\$ 79.3$ billion in loss payments compared with $\$ 51$ billion under TRIA in 2005. 
Table 4. Distribution of Losses under TRIA-2005 and if TRIA is Made Permanent (\$25 billion Loss in New York City)

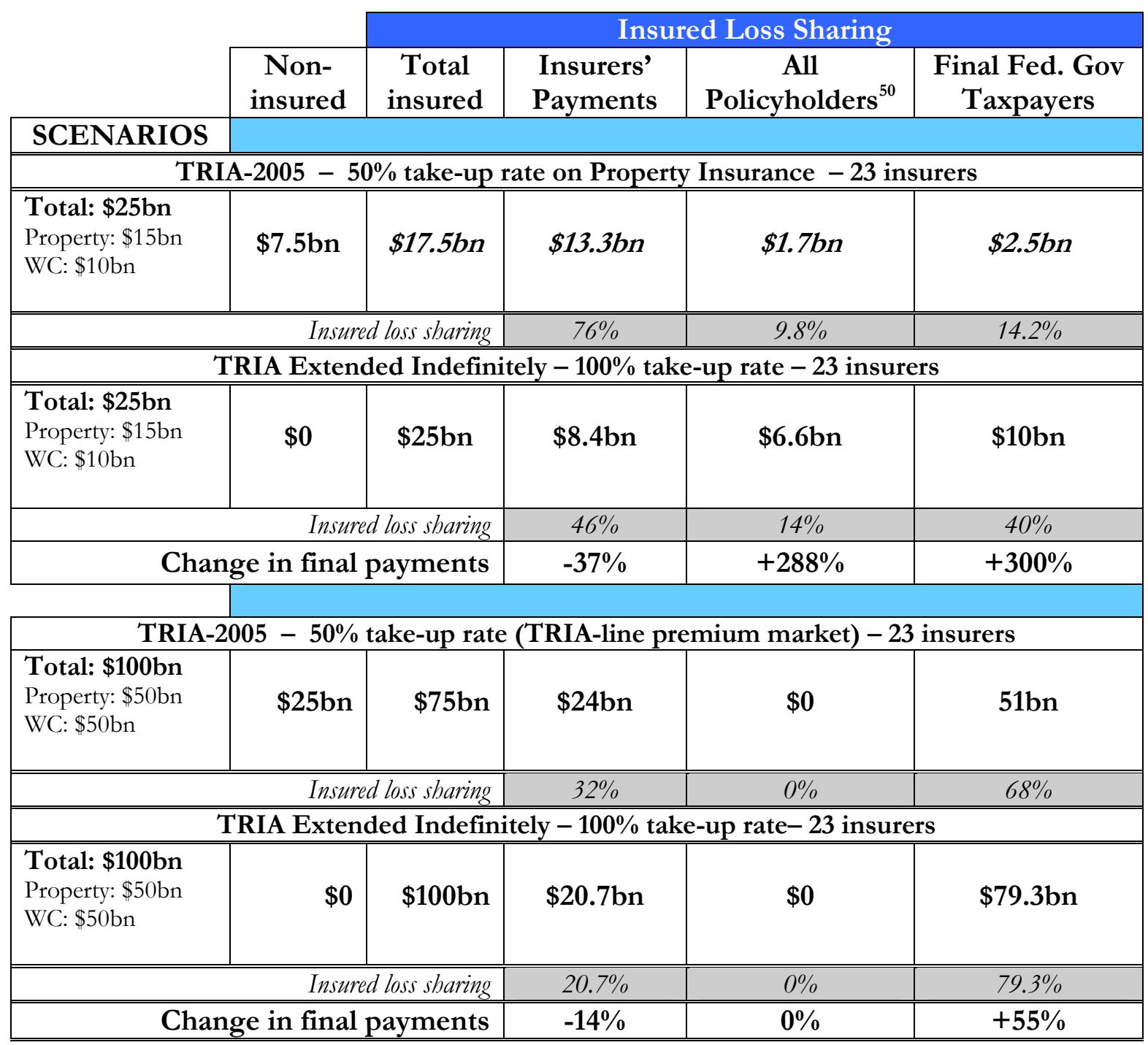

If one wants to design a program that encourages insurers to write coverage, then a permanent terrorism insurance program like TRIA or TRIEA will be successful due to the very large subsidy the government provides to any insurer whose losses exceed $D$. The very large insurers with low $D / S$ ratios will provide most of the coverage and pay very little after a terrorist attack compared with their aggregate exposure. They would keep all their premiums and transfer the loss to all commercial policyholders and taxpayers. This points to an inequity in this system, because the policyholders of those insurers who do not suffer any loss are responsible for the same amount of repayment to the government in the form of a surcharge as are policyholders in companies that suffered large losses and were subsidized by the government.

\footnotetext{
${ }^{50}$ The federal government is assumed to recoup the portion of insured loss it initially paid above insurers' payments up to an industry aggregate of $\$ 15$ billion in 2005 .
} 


\section{Rationale for Limiting Aggregate Exposure}

There are several reasons why insurers may not be willing to assume the large aggregate exposure implied by an $E^{*}$ gaming strategy. First, a larger $E^{*}$ increases the likelihood that an insurer will experience medium to large losses below its TRIA (or TRIEA) deductible with the more structures insurers cover in high-risk areas. In this sense insurers may decide to limit their aggregate exposure by estimating the likelihoods of different terrorist attack scenarios occurring. Insurers may then reduce their aggregate exposure by utilizing their survival constraint in a manner similar to the processes they follow for other catastrophic risks. Second, when an insurer provides coverage against terrorism it also provides insurance against all other events that could cause damage or losses to their property and/or claims from their workers' compensation coverage. When an insurer decides whether to write more terrorism coverage, it needs to consider its aggregate exposure from a much broader set of risks (e.g., fire, theft, job injury).

Insurers may be concerned that Congress will amend a permanent TRIA-like program if legislators observe the type of strategizing described above. Suppose insurers who expanded their coverage by focusing on $E^{*}$ were to be held responsible for 50 percent of their losses above their TRIA deductible. These insurers will very likely want to cancel some of their commercial policies for fear of incurring large claim costs after a terrorist attack. One reason why these insurers have not followed an $E^{*}$ gaming strategy today is their concern that a TRIA-like program will not be renewed in its current form.

\section{The Way Forward: A Perspective on Long-term Options for Terrorism Risk Financing}

Although TRIA has provided an important and necessary temporary solution to the problem of providing terrorism insurance to commercial firms, we do not believe it or its successor TRIEA is an equitable and efficient program in the long run. We now turn to a set of alternative options that involve the private and public sectors for providing protection against terrorism losses on a more permanent basis. These alternatives are not mutually exclusive. Some combination of these and perhaps other options should be considered in the design of a program that provides protection against terrorism losses while at the same time encouraging risk-reducing measures by those who are potential targets for a future attack.

\section{Deploy Capital of Potential Target Firms}

Modern enterprise risk management has shown that it often makes sense for a firm to use its own capital to absorb risk, rather than insuring against a loss. In these circumstances, the firm can manage the risk through its own capital management strategy. For example, the firm may lower its debt financing in relation to equity to be able to tolerate more risk. Other more focused strategies include the use of structured debt (e.g., warrants, convertible and forgivable debt) and more recently the use of contingent capital (i.e., financing that is contingent on the occurrence of specified 
events). Thus, we would envision that a large part of terrorism risk is, and will continue to be, absorbed by the firm's own capital, so that it is, in fact, self-insured. ${ }^{51}$

Those institutions providing long-term debt financing to developers could possibly underwrite potential losses from terrorism and charge higher interest rates to reflect the additional risk. Equity capital investors could hold more diversified portfolios, so no single investor would suffer a large and disproportionate diminution in the total value of assets in the event of an attack.

\section{Deploy Capital of Reinsurers}

One potential private market solution that has been discussed is to increase the transfer of risk through reinsurance (Congressional Budget Office, 2005). ${ }^{52}$ Since reinsurance portfolios normally cover sizable losses in the tails of the distribution, reinsurers normally need to hold relatively large amounts of capital compared with primary insurers. During the past several years, most major reinsurers experienced reductions in capital, in part due to the 9/11 attacks, and several of them were downgraded by rating agencies. They decided not to allocate much of their scarce capital to terrorism risk, instead focusing their capital on other lines.

Results from the survey of reinsurers undertaken, as part of the Wharton Risk center TRIA and Beyond, by the Reinsurance Association of America indicate that the reinsurance industry's capacity for providing terrorism coverage under the TRIA program in 2005 was in the range of \$5--6 billion. According to those surveyed, if a TRIA-like program were not in place, reinsurers would either maintain the same amount of reinsurance coverage or reduce the amount they provide.

More detailed analysis needs to take place as to the role that private reinsurance could play in providing protection against catastrophic losses from terrorism. One possibility would be a TRIA-like program without individual insurer deductibles that would only provide payments once losses exceeded a large aggregate threshold ${ }^{53}$. This approach would stimulate the demand for reinsurance and would avoid some of the distortions associated with individual insurer deductibles and inclusion of captives in the $\operatorname{program}^{54}$.

\footnotetext{
${ }^{51}$ For more details on strategies that firms can use to self-insurance against risks see Doherty, N. (2000), Integrated Risk Management, New York: McGraw-Hill.

${ }^{52}$ Congressional Budget Office (2005), Federal Terrorism Reinsurance: An Update, Washington, DC, January.

${ }^{53}$ Notably, the leading reinsurance companies reentered several European markets for terrorism insurance after $9 / 11$. Most of them did so because their exposure was limited and that they were all part of a pooled reinsurance tranche of a national program. See Michel-Kerjan, E. and Pedell, B. (2005), "Terrorism Risk Coverage in the Post- 9/11 Era: A Comparison of New Public-Private Partnerships in France, Germany and the U.S.," The Geneva Papers on Risk and Insurance, 30: 1, pp. 144-170. This article also discusses programs in Spain (established in 1954) and the United Kingdom (established in 1993; modified in 2003).

${ }^{54}$ End of 2004 , nearly $\$ 35$ billion in terrorism coverage capacity was provided by industry captives in the states of Vermont and Hawaii only (the two largest on-shore captive states in the U.S-700 and 150 licensed captives end of 2004, respectively). For a detailed discussion on captives in the context of terrorism insurance in the US, see Wharton Risk Center, Chapter 9 (2005).
} 
Another complementary option would be to base any federal reimbursement of terrorism losses on net (i.e., after reinsurance) losses without requiring reinsurers to make terrorism coverage available. Such a change might significantly increase the scope of reinsurance and associated risk spreading. The terms of reinsurance would reflect the federal backstop (i.e., the reinsurer's ability to be reimbursed for losses), thus reducing reinsurance prices. Primary insurers would be free to either buy reinsurance if available at the right price or keep similar exposures as under the current system.

\section{Reduce Tax Costs for Insurers and Reinsurers to Hold Capital}

U.S. federal tax policy increases the costs of private-sector arrangements for spreading catastrophe risk, thus reducing the supply of insurance and alternative riskspreading vehicles. Insurers cannot establish tax deductible reserves for events that have not occurred. More importantly, providing insurance against rare but potentially enormous losses requires insurers to hold large amounts of equity capital, which is primarily invested in marketable securities. Investors can readily purchase the same types of securities directly or through investment funds, in which case the returns on the securities are subject to personal taxes only. When held by an insurer to back the sale of its policies, the returns are taxed twice -- at the corporate level and at the personal level -because insurers cannot hold such capital in tax-deferred accounts. For the securities to be used to back policies, the premiums must therefore be high enough to compensate investors for the extra layer of taxes. The total cost can be very large for the amounts of capital that must be invested to back the sale of insurance for rare but potentially extreme events, such as large losses from terrorist attacks.

The private sector's capacity to offer coverage for losses from terrorism (and other extreme events) would therefore expand if insurers and reinsurers were allowed some form of tax-deferred reserves for terrorism coverage. Such a policy could reduce the costs to insurers and reinsurers of holding the large amounts of capital necessary to provide coverage. This should increase supply and reduce premium rates. A tax-deferred reserve approach should be weighed carefully in light of a number of potential benefits and possible drawbacks: a short-term reduction of tax revenues, the disadvantage of industry-specific tax rules, and the challenges of designing a system that meets the objectives of expanding capacity to insure losses from terrorism (and possibly other extreme events) without allowing significant unrelated tax deferral.

\section{Facilitate the Use of Terrorism Catastrophe Bonds 55}

A catastrophe bond transfers the risk of a large loss from the insurance/reinsurance industry to the financial markets. A significant market for catastrophe bonds to cover losses from terrorist attacks has not emerged since 9/11. To date, only three terrorism-related catastrophe bonds have been issued and these were part of multi-event coverage for other risks such as natural disasters and pandemics. For

\footnotetext{
55 This section is based on Kunreuther, H. and Michel-Kerjan, E. (2005) "Insuring Mega-Terrorism: Challenges and Perspectives". Report for the OECD Task Force on Terrorism Insurance. In OECD: Terrorism Insurance in OECD Countries, July 5.
} 
example, the first bond was issued in Europe in August 2003. The Fédération Internationale de Football Association (the world governing organization of association football [soccer]), which is organizing the 2006 World Cup in Germany, developed a \$262 million bond to protect its investment. Under very specific conditions, the catastrophe bond covers losses resulting from both natural and terrorist extreme events that would result in the cancellation of the World Cup game without the possibility of it being re-scheduled to $2007 .^{56}$

The lack of interest in new financial instruments for covering terrorism risk may be due to concern by investment managers that potentially a large loss from a catastrophe bond would hurt their reputations (and possibly their compensation). Another reason why there has been no market for terrorism catastrophe bonds might be evident in the reluctance of reinsurers to provide protection against this risk following the 9/11 terrorist attacks. Financial investors perceive reinsurers as experts in this market. Upon learning that the reinsurance industry required high premiums to provide protection against terrorism, investors were only willing to provide funds to cover losses from terrorism if they received a sufficiently high interest rate. ${ }^{57}$

Most investors and rating agencies consider terrorism models as too new and untested to be used in conjunction with a catastrophe bond covering terrorism risks. The models are viewed as providing useful information on the potential severity of the attacks but not on their frequency. Without the acceptance of these models by major rating agencies, the development of a large market for terrorism catastrophe bonds is unlikely ${ }^{58}$. In addition, institutional, tax and regulatory constraints have discouraged the growth of terrorism-related and other catastrophe bonds.

A study should be undertaken to analyze behavioral, institutional and regulatory obstacles to the development of a more robust market for terrorism catastrophe bonds, as well as the steps that would need to be taken to modify the current situation.

\section{Mutual Insurance Pools}

Another alternative would be to allow insurers to form an insurance pool to deal with specific lines of coverage, perhaps with some federal backing for large losses. In effect, a group of companies would provide reinsurance to each other. For example, firms insuring high-risk assets in the United States and around the world could form their own mutual insurance pools. This solution has the advantage of spreading the risk over a large number of insurers who join these pools, but it is unclear whether this alternative would provide adequate coverage against mega-terrorism. Pool solutions developed in several other countries should be analyzed in more detail to determine their potential application to the U.S. market ${ }^{59}$. The pool does not have to provide coverage for the entire country, but can be focused in certain types of risks and/or industries.

\footnotetext{
${ }^{56}$ Congressional Budget Office (2005), Federal Terrorism Reinsurance: An Update, Washington, DC, January. Kunreuther and Michel-Kerjan (2005), "Insurability of mega-Terrorism: Challenges and Perspectives", in OECD (2005); ibid.

${ }^{57}$ Kunreuther, H. (2002) "The Role of Insurance in Managing Extreme Events: Implications for Terrorism Coverage", Risk Analysis, 22: 427-37.

${ }^{58}$ U.S. General Accounting Office (GAO) (2003), Catastrophe Insurance Risks. Status of Efforts to Securitize Natural Catastrophe and Terrorism Risk. GAO-03-1033. Washington, D.C.: September 24.

${ }^{59}$ See OECD (2005), Terrorism Risk Insurance in OECD Countries, July 5.
} 


\section{Publicly Administered Mutual Insurance}

The need for federal protection against terrorism risks and those of other extreme events comes from the combination of two defects. The loss probability is highly uncertain and the maximum possible loss is considered to be large relative to the amount of private reinsurance and catastrophe bonds available to insurers. One strategy for addressing these two problems is to construct a type of publicly administered mutual insurance arrangement.

Two key conditions must hold for this arrangement to be feasible. First, although losses on individual properties can be highly correlated and aggregate damages can be large, the losses cannot be perfectly correlated. For example, the arrangement could absorb a severe attack on Houston, New York, or San Francisco, but not necessarily if the three cities were attacked simultaneously. Second, buyers need not agree on what they think the loss probability is in each site, but they must be able to agree (in the simplest case) that it is the same, or (in a more complex case) on what the relative likelihoods are. For example, all buyers might agree that a large-scale assault is twice as likely in Houston and New York as in San Francisco.

The insurance would work as follows for the case of a mutual insurance program protecting insurers providing terrorism coverage in these three cities. Each insurer would choose a level of protection through the mutual pool and pay an estimated premium. If no attack occurs on either site after a predefined period of time, any excess premiums above a certain threshold are returned to these insurers in proportion to their original purchase. Suppose a loss does occur in Houston, for example, and if its magnitude is less than resources accumulated by the pool to that point, all claims are paid. But if total insured losses exceed claims, insurance buyers are assessed an additional amount to cover claims. In this example, New York and San Francisco policyholders furnish the capital to cover excess claims in Houston. In effect, this arrangement uses as its source of excess capital the undamaged assets of pool participants who have not suffered a loss. Such an arrangement might be voluntary, but it might be made compulsory as well, with the ex post assessments proportional to the additional coverage that was made mandatory.

\section{Federal Reinsurance with Explicit Premiums}

Another possible response to the limited capacity of private insurers and reinsurers to furnish coverage against catastrophic losses is a federal reinsurance program with explicit premiums. The most obvious technique for pricing federal reinsurance would be for the government to calculate a premium. It would make its own estimate of the probability of a major attack and the extent of the damages, calculate the expected value of the loss, add a modest amount for administrative expenses, possibly tack on a "risk premium", and offer unlimited amounts of coverage for sale at this premium.

Under a federal reinsurance program, in years without any major terrorist attack, no benefits would be paid out. But if an attack occurred, these government's collected funds would be used to cover the catastrophic portion of the losses against which insurers had purchased federal reinsurance. If the losses protected by federal reinsurance exceeded the premiums collected, the government would have to finance these claims from other 
sources of taxpayer revenue. Over time, if the premiums accurately reflected the risks of terrorist attacks, the government reinsurance fund would be replenished.

\section{Considering Covering both Domestic and Foreign Terrorism ${ }^{60}$}

Another question that needs to be addressed is whether the arbitrary distinction that the current U.S. terrorism risk insurance program makes between so-called "foreign" and "domestic" terrorism reflects the current nature of the terrorism threat ${ }^{61}$. This poses at least two major problems.

First, the evolution of international terrorist activities from more locally organized and even national groups to global organization makes it difficult to distinguish between a domestic and foreign terrorism, as illustrated by the July 2005 bombings in London, $\mathrm{UK}^{62}$. Some of these terrorists had been trained to kill in Pakistan. Should one thus conclude that they were "acting on behalf of a foreign person or foreign interest"? On the other hand, they had been living in London for years, studying or working there. Should one conclude they acted on behalf of their own ideology? In that case, should we conclude that the nearly 800 casualties were victims of domestic terrorism? Had these events been more devastating and occurred in the U.S., would they have qualified for TRIA coverage? Today this gray zone is likely to inflict legal costs to both victims and insurers, and considerably delay claims payments to victims of the attacks.

Second, the decision to exclude domestic terrorism from TRIA and its extension because it was not considered a serious threat needs to be reevaluated in the light of the current threats posed by extremist groups in the United States ${ }^{63}$. Data on domestic terrorism from the U.S. Federal Bureau of Investigation reveal that over 350 acts of domestic terrorism have been perpetrated on the U.S. soil during the period 1980-2001. Although the annual number of such attacks decreased during the 1980s and mid 1990s, it started increasing again in the past ten years averaging 15 attacks a year nationwide

\footnotetext{
${ }^{60} \mathrm{We}$ appreciated discussions on this domestic terrorism issue with James O. Ellis III (Memorial Institute for the Prevention of Terrorism in Oklahoma City), Mark Potok (Southern Poverty Law Center) and with Henry Schuster (CNN).

${ }^{61}$ TRIA stipulates that a terrorist attack would be certified as an act of terrorism only if it is perpetrated by "an individual or individuals acting on behalf of any foreign person or foreign interest, as part of an effort to coerce the civilian population of the United States or to influence the policy or affect the conduct of the United States Government by coercion."

${ }^{62}$ For an insightful analysis of the London bombing in that regard, see the series of articles in The Economist (2005), "In Europe's midst”, July 16.

${ }^{63}$ For discussions on the nature of these groups and their operation, see Ellis III, J. "Terrorism in the Homeland: A Brief Historical Survey of Violent Extremism in the United States", Memorial Institute for the Prevention of Terrorism, Oklahoma City; Hoffman, B. (1998) Inside Terrorism. New York: Columbia University Press; Stern, J.. (2003). Terror in the Name of God: Why Religious Militants Kill. New York: Harper Collins. Potok, M. (2004), "The American Radical Right: The 1990s and Beyond." in Eatwell, R. and Mudde, C. (eds) Western Democracies and the New Extreme Right Challenge, Routledge; Frey, B. (2004) Dealing with Terrorism: Stick or Carrot, Edward Elgar Publishing; Chalk, P. Hoffman, Reville, R and B. Kasupski, A-B. (2005) Trends in Terrorism, Santa Monica, CA: Rand Corporation, June.
} 
during the period $1996-2001^{64}$. It is likely that this increase has been galvanized by antiglobalization imperatives ${ }^{65}$.

Consideration should therefore be given as to whether it is desirable to include domestic terrorism as part of the events covered in a national terrorism insurance program. The analysis should consider whether the economic rationale for government involvement in covering the risk of large losses from domestic terrorism is any different from foreign terrorism, as well as the problems associated with the arbitrary distinction made by TRIA between "foreign" and "domestic" acts.

\section{Developing Incentive Programs for Encouraging Mitigation}

Moreover, further analysis is needed to link mitigation and insurance coverage in a more systematic way. It would be important to develop incentive programs to adequately reward private sector investment in security, for example by lowering the price of terrorism risk financing and/or by providing any other economic incentives (e.g., more favorable tax treatment). It is worth noting, however, that the absence of a link between insurance and investment in security is not specific to the United State ${ }^{66}$-- most industrialized countries have not yet implemented such incentive programs either.

\section{Conclusions}

Today, four and a half years after 9/11, the question as to who should pay for the economic consequences of a terrorist attack on the United States has not yet received the attention it deserves. As stated by the White House in its 2002 National Strategy, homeland security is "the concerted effort to prevent attacks, reduce America's vulnerability to terrorism, and minimize the damage and recover from attacks that do occur" ${ }^{\prime 67}$. To succeed, security must be a comprehensive national effort.

The new law extending TRIA for two additional years directs the President's Working Group on Financial Markets to study long-term availability and affordability of coverage for terrorism losses. This group must submit a report of its findings to the House Financial Services and Senate Banking Committees by September 30, 2006. As we have already advocated ${ }^{68}$, Congress or the White House should consider establishing a broader national commission on terrorism risk coverage before permanent legislation is enacted. Indeed, the challenges associated with terrorism risk financing are fundamental, and they will not be solved overnight. In addition to the insurance industry, there is a need to include representation on such a National Commission from sectors of the economy who are affected by the terrorism risk such energy, transportation, real estate

${ }^{64}$ U.S. Department of Justice, Federal Bureau of Investigation (2002), "Terrorism 2000/2001", FBI, Counterterrorism division, Publication 0328.

${ }^{66}$ Auerswald, P., Branscomb, L., LaPorte, T., and Michel-Kerjan, E. (eds) Seeds of Disaster, Roots of Response. How Private Action Can Reduce Public Vulnerability, Cambridge University Press, forthcoming.

${ }^{67}$ The White House (2002), National Strategy for Homeland Security. Washington, DC., July.

${ }^{68}$ See Kunreuther, H. and Michel-Kerjan, E. (2005), "Terrorism Insurance 2005. Where Do We Go from Here?" Regulation. The Cato Review for Business and Government, Washington, DC: The Cato Institute, Spring 2005 pp. 44-51. See also The Economist (2005), "In Europe's midst", July 16 and The Economist (2005), "Horrible Business: Terror Insurance", November 19. 
and health. U.S. Treasury representation should be supplemented by key individuals from federal agencies, such as the Department of Homeland Security and the Department of Defense who are concerned with national security issues.

Such a National Commission could explore the objectives of a terrorism risk financing program and how to achieve them through alternative risk sharing mechanisms. In addressing these issues there is a need for collaboration with the homeland security/intelligence community to measure what potential threats are. A National Commission could also examine how other countries cope with the terrorism risk to determine whether these approaches merit consideration for the United States. The insurance infrastructure would undoubtedly play a key role in such a program, but it should be viewed as part of a broader strategy for dealing with terrorism. For example, the public and private sectors could provide economic incentives in the form of lower taxes, subsidies or lower insurance premiums to encourage those at risk to adopt higher security and loss reduction measures. There will likely be a need for well-enforced regulations and standards to complement these incentive programs.

The design of a terrorism insurance program reflects society's view as to who should pay for the losses from the next attack ${ }^{69}$. Hurricane Katrina is likely to impact on how citizens, firms and policymakers envision the role and responsibility of the public and private sectors in providing adequate protection to victims of large-scale disasters and the importance of understanding how actions taken before a disaster impacts on the need for financial assistance after a catastrophic event occurs ${ }^{70}$. Similar questions need to be posed with respect to the terrorism risk. A well-designed terrorism insurance program has the potential of encouraging mitigation measures while at the same time alleviating the need for large-scale public sector involvement following the next attack.

\footnotetext{
${ }^{69}$ Indeed, other countries have implemented programs quite different from TRIA; see Michel-Kerjan, E. and Pedell, B. (2005), "Terrorism Risk Coverage in the Post- 9/11 Era: A Comparison of New PublicPrivate Partnerships in France, Germany and the U.S.," The Geneva Papers on Risk and Insurance, 30: 1, pp. 144-170. See also Organization for Economic Cooperation and Development (2005), Terrorism Insurance in OECD Countries. Paris: OECD, July 5.

${ }^{70}$ Daniels, R., Kellt, D. and Kunreuther, H. (eds) (2006), On Risk and Disaster: Lessons from Hurricane Katrina. University of Pennsylvania Press.
} 


\section{APPENDIX 1 \\ Deductible over Surplus Ratios: 2003 to 2005 and Prospective Analyses 2006-2007}

Using data provided by A.M. Best, we undertook an analysis of the top 463 companies $^{71}$ ranked by their 2004 TRIA lines direct earned premiums (larger than $\$ 10$ million). For each insurer, we had the following data:

- Total direct earned premiums all lines;

- Total direct earned premiums (DEP) for TRIA lines;

- Surplus $(S)$.

We determined the deductible over surplus $(D / S)$ ratio for the three years of TRIA operation: 2003, 2004 and 2005. Table A provides the data for determining the $D / S$ ratio for 2005 when $\mathrm{D}=15$ percent and it also shows these ratios for 2004 and 2003 when $\mathrm{D}=$ 10 and 7 percent, respectively, for the top 30 insurers (ranked by total TRIA DEP in 2004). Note that in 2003 only three insurers in the top 30 had a ratio $D / S$ ratios equal to or higher than 15 percent, while this number increased to 14 insurers in 2005.

\section{Prospective Analysis: Impact of TRIA Extended to 2007 on $D / S$ ratios}

Below we show how the extension of TRIA would impact on the $D / S$ ratio for the top 30 insurers in the U.S. for 2006 and 2007. The new deductible is increased to 17.5 percent of TRIA-line DEP in 2006, and 20 percent in 2007.

Methodology The study is undertaken for the top 30 insurers. In order to determine $D / S$ (2006) and $D / S$ (2007) for each company under these two scenarios, we need to know what would be their TRIA-lines DEP and their surpluses in 2005 and 2006, respectively. We base our analysis on the annual percentage change in these two numbers over the three-year period (2002-2004) for each of the thirty companies. We then extrapolate these figures to estimate DEP for TRIA lines and surpluses $(S)$ for 2005 and 2006. Table A presents the result of this analysis. With the deductible increased to 20 percent in 2007, 6 of the 10 largest insurers will have a $D / S$ ratio that will be 20 percent or greater.

\footnotetext{
${ }^{71}$ The original sample of insurers with a 2004 total TRIA-line direct earned premium above $\$ 10$ million was made of 466 insurers; but partial data were missing for 3 of them. As discussed, among these 463 insurers, our 2004 selected sample is made of the 451 insurers that also appear in the 2002 and 2003 data sets.
} 
Table A. 2003-2007: Prospective Analysis D/S Ratios for the 30 Largest Insurers, 2003-2007

$\mathrm{D}=\mathbf{1 7 . 5 \%}$ DEP in 2006 and 20\% DEP in 2007 (all amounts in \$ million)

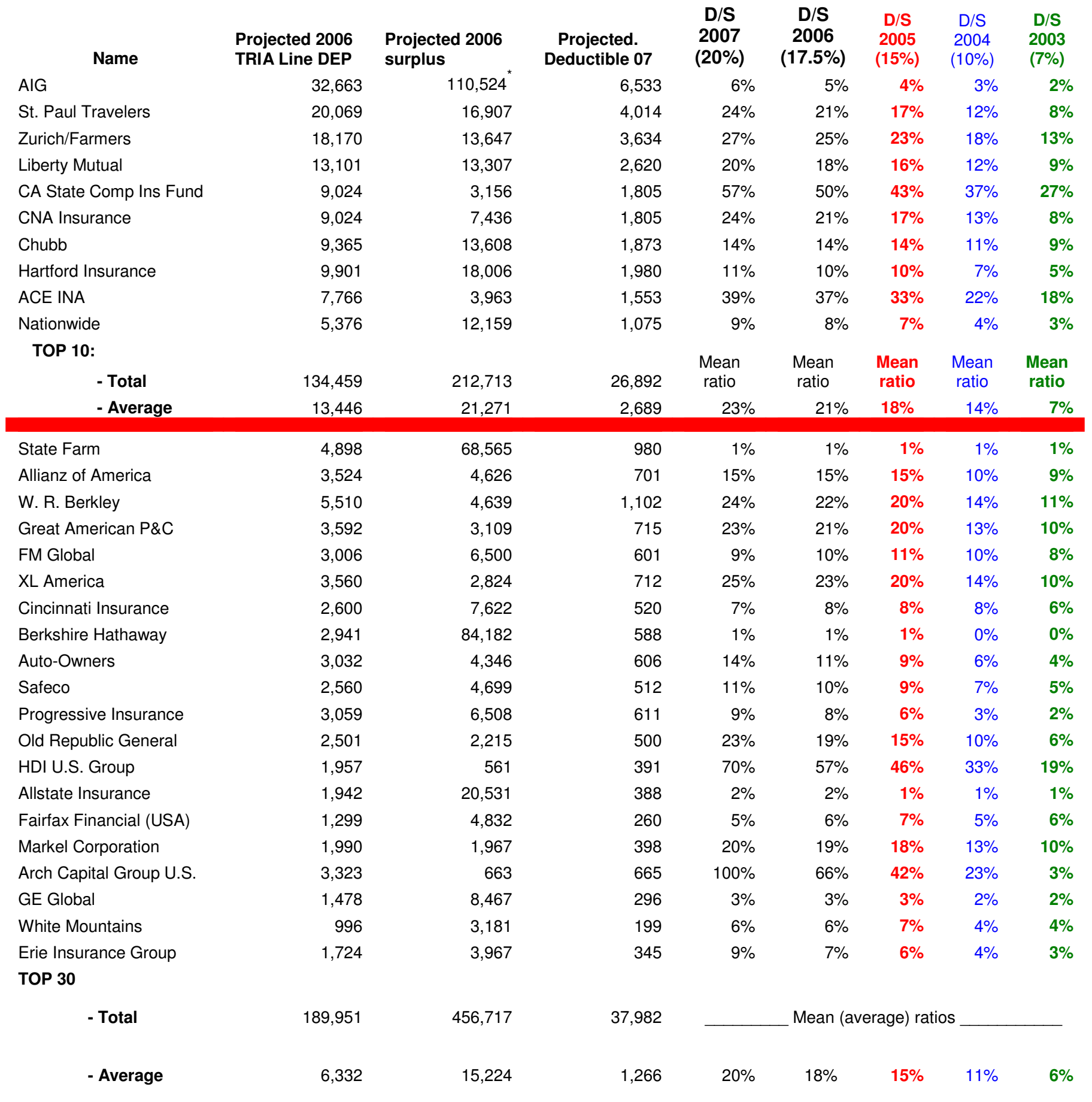

\footnotetext{
* This represents shareholders' equity rather than policyholders' surplus that seems more appropriate here.
} 
APPENDIX 2

Brief side by side comparison between TRIA 2005 and TRIEA 2006-2007

\begin{tabular}{|c|c|c|c|}
\hline & TRIA & \multicolumn{2}{|c|}{$\begin{array}{l}\text { Extension of TRIA } \\
\text { (TRIEA / S. 467) }\end{array}$} \\
\hline & 2005 & 2006 & 2007 \\
\hline $\begin{array}{c}\text { Program trigger } \\
(\ll \text { per event } » \text { in 06-07) }\end{array}$ & $\$ 5$ million & $\$ 50$ million & $\$ 100$ million \\
\hline $\begin{array}{l}\text { Insurer's deductible } \\
\text { (\% DEP previous year) }\end{array}$ & $15 \%$ & $17.5 \%$ & $20 \%$ \\
\hline $\begin{array}{c}\text { Federal share } \\
\text { (\% above insurers' } \\
\text { deductible) }\end{array}$ & $90 \%$ & $90 \%$ & $85 \%$ \\
\hline $\begin{array}{c}\text { Industry aggregate } \\
\text { retention/recoupment } \\
\text { threshold }\end{array}$ & $\$ 15$ billion & $\$ 25$ billion & $\$ 27.5$ billion \\
\hline Annual Program Cap & $\$ 100$ billion & $\$ 100$ billion & $\$ 100$ billion \\
\hline
\end{tabular}

